\title{
Kennsluaðferðir í 130 kennslustundum í framhaldsskólum
}

\author{
Ingvar Sigurgeirsson, Elsa Eiríksdóttir og Ingólfur Ásgeir Jóhannesson \\ Abstract Um höfundana $\backslash$ About the authors $>$ Heimildir
}

Í pessari grein er brugðið upp mynd af kennsluaðferðum sem framhaldsskólakennarar notuðu í 130 kennslustundum og pví hvaða aðferðir voru algengastar í ólíkum námsgreinum eða námsgreinasviðum. Gerð er grein fyrir ýmsum líkönum sem hafa verið notuð við að flokka kennsluaðferðir, svo sem flokkun í kennarastýrðar (e. teacher-centered) eða nemendamiðaðar (e. student-centered) aðferðir og flokkun eftir pví hvers konar kenningaramma um nám aðferðirnar byggjast á. Líkan sem hefur birst í bókinni Litróf kennsluaðferðanna var notað til að greina kennsluaðferðirnar og var einnig lagt mat á notagildi pess. Rannsóknargögn voru vettvangslýsingar úr 130 kennslustundum sem fylgst var með í rannsókninni Starfshattir i framhaldsskólum á árunum 2013 og 2014. Langflestar kennsluaðferðirnar féllu í tvo flokka, pað er útlistunarkennslu annars vegar og pjálfunaræfingar og skrifleg verkefni hins vegar. Kennsluaðferðir voru nokkuð ólíkar eftir greinum og skáru íslenska og iðn- og starfsnámsgreinar sig talsvert úr fyrir fjölbreytni aðferða. Einsleitust var kennslan í stærðfræði. Í ljós kom að líkanið sem lagt var upp með til að skoða kennsluaðferðirnar náði betur yfir vel skilgreindar aðferðir en pær stundir par sem beitt var flóknum eða samsettum aðferðum. Greining á kennsluaðferðum hefur hagnýtt gildi með tilliti til stefnumörkunar og notkunar í kennaramenntun, og fræðilegt gildi í umræðu um kennsluaðferðir og flokkun peirra.

Efnisorð: kennsluaðferðir, framhaldsskóli, flokkunarkerfi kennsluaðferða

\section{Inngangur}

Í umræðum um skólastarf ber mikið á kröfum um fjölbreytni í kennslu og að kennarar hafi vald á að nota margvíslegar aðferðir. Framhaldsskólastigið er ekki undanskilið í pessari umræðu. Í aðalnámskrá framhaldsskóla er pví haldið fram að „fjölbreytni í vinnubrögðum og kennsluaðferðum sé ein forsenda pess að nemendur öðlist margvíslega hæfni“ og að „,mikilvægt sé að hafa í huga að ... sömu aðferðir henta ekki öllum nemendum jafn vel“" (Mennta- og menningarmálaráðuneytið, 2011, bls. 29).

Áhugavert er frá pessu sjónarhorni að fá innsýn í pað hvaða aðferðum kennarar beita við kennslu í framhaldsskólum. Í pessari grein eru notuð gögn úr rannsókninni Starfshattir í framhaldsskólum sem gerð var á árunum 2013-2014 í níu ólíkum framhaldsskólum. Athugendur skráđu ítarlegar vettvangslýsingar í 130 kennslustundum og héldu til haga miklum upplýsingum um hverja kennslustund, meðal annars um kennsluaðferðir, samskipti kennara og nemenda, framkomu kennara, námsgögn, upplýsingatækni og ástundun nemenda. Dessar vettvangslýsingar voru greindar til að skoða hvaða kennsluaðferðir voru notaðar. Markmið greinarinnar er tvípætt: Annars vegar að bregða upp yfirliti um pær kennsluaðferðir sem kennarar beittu í 130 kennslustundum 
í framhaldsskólunum níu. Athugað var hvaða aðferðir reyndust algengastar, bæði yfirleitt en einnig eftir námsgreinum og námsgreinasviðum. Við greininguna var stuðst við skilgreiningar og flokkun kennsluaðferða í bókinni Litróf kennsluaðferðanna (Ingvar Sigurgeirsson, 2013). Annað markmið greinarinnar er að leggja mat á notagildi peirrar flokkunar kennsluaðferða sem sett er fram í Litrófinu og er í pessari grein kölluð Litrófskerfið.

Dessi greining hefur hagnýtt gildi fyrir stefnumörkun í kennaramenntun, fyrir innra starf framhaldsskóla og starfspróun kennara, og fræðilegt gildi í umræðum um kennsluaðferðir og flokkun peirra. Í nýlegri skýrslu frá Efnahags- og framfarastofnuninni (OECD) er pví haldið fram að kennaraháskólar kunni að leggja of litla áherslu á kennslufræði greinar (e. pedagogical content knowledge, sjá Shulman, 1986), almenna kennslufræðibekkingu (e. general pedagogical knowledge) og nýja pekkingu úr menntavísindum. En jafnframt er tekið fram að pessi fullyrðing sé byggð á tilfinningu kennara um undirbúning sinn, pví að kerfisbundna pekkingu á pví sem fram fer í kennslustofunum sé erfiðara að finna (Schleicher, 2018, bls. 62). Dessi rannsókn er framlag til umræðunnar um pað hvað par fer fram.

\section{Kennsluaðferðir}

Kennsluaðferð (e. instructional strategy, teaching strategy, instructional method, teaching method) er sú aðferð sem kennarinn beitir við kennslu til að stuðla að námi og styðja nemendur við að ná settum markmiðum (Burden og Byrd, 2016). Kennsluaðferðir taka til helstu pátta í skipulagi kennslu og má par nefna samskipti við nemendur og ákvarðanir um viðfangsefni og framsetningu námsefnis (Ingvar Sigurgeirsson, 2013; Stronge og Xu, 2016). Kennsluaðferðir, í pessum skilningi, gætu pví verið reifun efnis í fyrirlestri, umræðuverkefni eða verklegar æfingar og í einni og sömu kennslustund getur kennari beitt mismunandi aðferðum til að vinna að ólíkum markmiðum.

Kennsluaðferðir stýra pví sem fer fram í kennslustundum, vinnu og athöfnum nemenda, og pað hefur aftur gjarnan áhrif á samskipti kennara og nemenda. Val á kennsluaðferð hefur pví óhjákvæmileg áhrif á pekkingarsköpun nemenda og pað nám sem fer fram í kennslustund, enda benda rannsóknir til pess að val á kennsluaðferðum skipti máli fyrir nám pótt árangur sé einnig háður beitingu, aðstæðum og pekkingu kennara (Hattie, 2009). Í pessari rannsókn er áherslan fyrst og fremst á að skoða val kennara á kennsluaðferð, p.e. hvaða kennsluaðferðum kennarar beita við kennslu, en ekki á afleiðingar pessa vals fyrir nám nemenda.

Gagnið af pví að flokka kennsluaðferðir felst að hluta til í pví að auðveldara verður að ná utan um víðfeðmt svið peirra með pví að skipa saman skyldum aðferðum með hliðsjón af tilteknum eiginleikum. Pannig gefst fræðimönnum færi á að skoða einkenni aðferða í rannsóknum á skólastarfi eða mæla með aðferðum sem byggjast á rannsóknum eða tilteknum kenningarlegum grunni. Eins má benda á mikilvægi pess að kynna verðandi og starfandi kennurum úrval kennsluaðferða svo að peir geti valið sér aðferðir sem best henta hverju sinni með hliðsjón af nemendahópnum, markmiðum, aðstæðum eða kennslufræðilegri sýn. Gagnsemi flokkunar er pví bæði hagnýt og fræðileg.

\section{Flokkun kennsluaðferða}

Hægt er að flokka eða greina kennsluaðferðir á marga vegu, til dæmis með hliðsjón af pví hversu mikil krafa er gerð um pátttöku eða virkni nemenda (kennarastýrð - nemendamiðuð), hversu stórt hlutverk upplýsingatækni leikur í notkun (tæknivædd - ótæknivædd; e. high-tech, low-tech), eftir fjölda nemenda sem kennt er í einu (einstaklingur, hópur, fjöldi), eftir stöðu nemenda eða fyrri pekkingu peirra, eftir pví hversu mikla ábyrgð nemandinn tekur (e. gradual release of responsibility), hvort pær byggjast á afleiðslu eða aðleiðslu, hvort kennsluaðferðirnar pykja hefðbundnar (e. traditional), gagnreyndar (e. evidence-based) eða nýstárlegar (e. progressive) eða eftir pví hvaða kenningaramma um nám pær tengjast (Burden og Byrd, 2016; Joyce, Weil og Calhoun, 
2015; Mosston og Ashworth, 1990; Stronge og Xu, 2016). Hversu margar víddir eða flokkar eru notaðir til aðgreiningar er mismunandi eftir kerfum, áherslum og kenningarlegum bakgrunni.

Hér er vikið sérstaklega að tveimur leiðum; annars vegar er flokkun í kennarastýrðar og nemendamiðaðar kennsluaðferðir og hins vegar flokkun eftir kenningaramma. Dessar leiðir eiga pað sameiginlegt að vera bæði pekktar og mikið notaðar (Burden og Byrd, 2016; Joyce o.fl., 2015). Loks er fjallað sérstaklega um flokkunarkerfi sem próað var á Íslandi í tengslum við rannsóknir á grunnskólakennslu, Litrófskerfið.

\section{Kennarastýrðar eða nemendamiðaðar kennsluaðferðir}

Ein helsta leiðin sem notuð er til flokkunar á kennsluaðferðum er að skipta peim í kennarastýrðar (e. teacher-centered) og nemendamiðaðar (e. student-centered) aðferðir (Burden og Byrd, 2016; Lindblom-Ylänne, Trigwell, Nevgi og Ashwin, 2006). Svipuð skipting er einnig oft kennd við beinar (e. direct) eða óbeinar (e. indirect) aðferðir (Burden og Byrd, 2016). Kennarastýrðar (eða beinar) kennsluaðferðir snúa fyrst og fremst að kennaranum; áherslan er á að kennarinn miðli upplýsingum til nemenda og hvað hann geri til að nám eigi sér stað. Sem dæmi um kennarastýrðar kennsluaðferðir má nefna fyrirlestra og sýnikennslu eða skriflegar eða verklegar æfingar. Nemendamiðaðar (eða óbeinar) aðferðir snúa fyrst og fremst að nemendum og áherslu á stuðning við pekkingarsköpun peirra. Dar er sjónum beint að pví sem nemendur gera og hvernig peir vinna með námsefni. Dæmi um nemendamiðaðar aðferðir eru lausnarleitarnám (e. problembased instruction) og uppgötvunarnám (e. discovery learning).

Rannsóknir hafa sýnt talsverðan mun á notkun kennsluaðferða eftir námsgreinum. Sem dæmi má nefna að kennarar sem kenna „hörð“ vísindi á háskólastigi, svo sem náttúruvísindi, verkfræði og læknisfræði, pykja líklegri til að beita kennarastýrðum aðferðum, en peir sem kenna „mjúk“ vísindi, innan félags- og hugvísinda, beiti frekar nemendamiðuðum aðferðum (Lindblom-Ylänne o.fl., 2006; Lueddeke, 2003). Pó virðist kennslufræðileg sýn einnig hafa áhrif; Lueddeke (2003) sýndi fram á að faggrein og hugmyndir kennara um kennslu voru lykilbreytur pegar spá skyldi fyrir um pað hvernig kennarar nálguðust kennslu á háskólastigi. Ytri aðstæður kennslu hafa einnig áhrif, til dæmis hvort um er að ræða ný námskeið eða reglubundna kennslu, vinnuálag kennara og stærð nemendahópsins (Anna Ólafsdóttir, 2014; Lindblom-Ylänne o.fl., 2006; Trigwell og Prosser, 2004), en nemendamiðaðar aðferðir virðast oftar vera notaðar pegar kennarar eru ekki undir of miklu vinnuálagi, nemendahópurinn er ekki of stór og er nægjanlega vel undirbúinn og kennarar ráđa pví hvað er kennt (Trigwell og Prosser, 2004).

\section{Kenningarammi við flokkun kennsluaðferða}

Eitt pekktasta flokkunarkerfi kennsluaðferða er kerfi Joyce og Weil sem pau birtu í bókinni Models of Teaching sem fyrst kom út árið 1972. Hugmynd peirra var að lýsa úrvali kennsluaðferða sem ættu sér traustan fræðilegan grunn og byggðust á tiltekinni kenningarlegri sýn á pað hvernig nám fer fram (Joyce og Weil, 1972; Joyce o.fl., 2015). Dau skiptu kenningarlegum nálgunum í fjóra aðalflokka og skipa kennsluaðferðum í pessa aðalflokka eftir peim kenningaramma um nám sem aðferðin byggðist á.

1. Hugræni kenningaramminn (e. the information-processing family) byggist á kenningum um nám sem leggja áherslu á pað hvernig mannshugurinn vinnur með upplýsingar og sérstaklega hvernig pær eru skráđar og endurheimtar úr minni. Dessum aðalflokki tilheyra aðferðir sem miða að pekkingaröflun, skilningi og hugsun. Hér má nefna fyrirlestra, umræðu- og spurnaraðferðir og leitaraðferðir.

2. Félagslegi kenningaramminn (e. the social family) byggist á félagsnámskenningum. Í pessum flokki eru ýmsar samvinnunámsaðferðir og hópvinnubrögð par sem nemendur vinna saman að upplýsingaöflun, og einnig hlutverkaleikir. 
3. Persónubundni kenningaramminn (e. the personal family) byggist á kenningum um persónuproska og sjálfsskilning. Hér má nefna kennsluhætti par sem kennarinn er í hlutverki ráđgjafa sem leitast við að fá nemendur til að taka sem mesta ábyrgð á námi sínu.

4. Atferliskenningaramminn (e. the behavioral systems family) byggist á atferlis-fræðilegum kenningum um nám. Í pessum flokki eru ýmsar aðferðir sem byggjast á pví að skipuleggja nám með kerfisbundnum hætti og móta pað með styrkingu (e. reinforcement), til dæmis hlítarnámsaðferðir (e. mastery learning), bein kennsla (e. direct instruction) og hermileikir (e. simulation games).

Ekki er gert ráð fyrir að hver kennari samsami sig einum tilteknum kenningaramma heldur nýti sér aðferðir eftir viðfangsefnum og aðstæðum og blandi jafnvel saman aðferðum sem tilheyri ólíkum aðalflokkum í einni og sömu kennslustund. Dannig er litið á flokkunarkerfið sem yfirlit um pau verkfæri sem kennari getur tileinkað sér til að ná árangri í starfi sínu (Joyce, Calhoun og Hopkins, 1997; Joyce o.fl., 2015). Flokkunin er fyrst og fremst byggð á kenningarlegri umfjöllun og röklegum forsendum en gert er ráð fyrir að stuðningur rannsókna innan pess kenningaramma sem aðferðin byggist á, ásamt rannsóknum á einstökum aðferðum, dugi til að staðfesta gildi aðferða (Joyce o.fl., 2015).

\section{Litróf kennsluaðferðanna}

Á Íslandi hefur bókin Litróf kennsluaðferðanna (Ingvar Sigurgeirsson, 1999, 2013) verið mikið notuð í menntun kennara og flokkunarkerfi kennsluaðferða sem par er sett fram notað til að kynna kennaranemum margbreytilegar kennsluaðferðir. Forsendur pess flokkunarkerfis sem bókin byggist á eru fyrst og fremst kennslufræðilegar og er hugmyndin að færa kennurum hagnýt verkfæri inn í skólastofuna.

Litrófskerfið varð til með peim hætti að farið var yfir ýmis flokkunarkerfi (sjá til dæmis Joyce, Weil og Showers, 1992; Kaplan, 1990; Lemlech, 1994; Mosston og Ashworth, 1990; Ornstein, 1990) í leit að fyrirmynd sem nota mætti í íslenska handbók fyrir kennara og kennaraefni um kennsluaðferðir (Ingvar Sigurgeirsson, 1999). En niðurstöður vettvangsrannsókna í grunnskólum (Ingvar Sigurgeirsson, 1992, 1994) leiddu í ljós að kennarar beittu ýmsum aðferðum sem ekki reyndist auðvelt að flokka eftir peim kerfum sem til voru. Баð varð úr að gera tilraun til að próa eigið líkan, sem einnig hefði pað sérstaka markmið að sýna fram á fjölbreytni kennsluaðferða. Detta var meðal annars gert með pví að hafa flokkana fleiri en í flestum öðrum flokkunarkerfum, eða níu talsins (sbr. töflu 1).

Í líkaninu er kennsluaðferðum skipt í níu flokka eftir meginmarkmiðum og áherslum peirra, eftir pví hvort pær „eiga sér sameiginlega eða náskylda aðferðafræði og gera pví svipaðar kröfur til kennara og nemenda“ (Ingvar Sigurgeirsson, 2013, bls. 55). Flokkarnir níu eru: (1) útlistunarkennsla, (2) pulunám og pjálfunaræfingar, (3) verklegar æfingar, (4) umræðu- og spurnaraðferðir, (5) innlifunaraðferðir og tjáning, (6) prautalausnir, (7) leitaraðferðir, (8) hópvinnubrögð og (9) sjálfstæð, skapandi viðfangsefni. Undir hvern flokk falla svo hinar ýmsar kennsluaðferðir sem bera einkenni flokksins (Ingvar Sigurgeirsson, 2013), sjá töflu 1. 
Tafla 1. Flokkar kennsluaðferða og dæmi um kennsluaðferðir samkvæmt Litrófskerfinu (Ingvar Sigurgeirsson, 2013).

\begin{tabular}{|c|c|c|}
\hline $\begin{array}{l}\text { Flokkar } \\
\text { kennsluaðferða }\end{array}$ & Dæmi um kennsluaðferðir * & Markmið / áherslur \\
\hline $\begin{array}{l}\text { 1. Útlistunar- } \\
\text { kennsla }\end{array}$ & $\begin{array}{l}\text { Fyrirlestrar, sýnikennsla, } \\
\text { skoðunarferðir, gestafyrirlestrar, } \\
\text { kvikmyndasýningar }\end{array}$ & $\begin{array}{l}\text { Fræða - miðla - útskýra - efla } \\
\text { skilning - vekja til umhugsunar }\end{array}$ \\
\hline $\begin{array}{l}\text { 2. Dulunám og } \\
\text { pjálfunaræfingar }\end{array}$ & $\begin{array}{l}\text { Dulunám, endurtekningaræfingar, } \\
\text { spurningahríð, skriflegar æfingar, } \\
\text { lesið, spurt og spjallað, námsleikir, } \\
\text { boðnámsaðferðir, pjálfunarforrit }\end{array}$ & $\begin{array}{l}\text { Kanna pekkingu nemenda og } \\
\text { festa hana í minni eða pjálfa } \\
\text { leikni }\end{array}$ \\
\hline $\begin{array}{l}\text { 3. Verklegar } \\
\text { afingar }\end{array}$ & Verklegar æfingar & Djálfa vinnubrögð - efla leikni \\
\hline $\begin{array}{l}\text { 4. Umræðu- og } \\
\text { spurnaradferðir }\end{array}$ & $\begin{array}{l}\text { Samræðuaðferðir, pankahríð, } \\
\text { umræðuhópar, málstofur, } \\
\text { pallborðsumræður, málfundir, } \\
\text { „réttarhöld““ }\end{array}$ & $\begin{array}{l}\text { Vekja til umhugsunar - pjálfa } \\
\text { rökhugsun - kenna nemendum } \\
\text { að tjá sig, rökræða og taka tillit til } \\
\text { annarra }\end{array}$ \\
\hline $\begin{array}{l}\text { 5. Innlifunar- } \\
\text { aðferðir og } \\
\text { tjáning }\end{array}$ & $\begin{array}{l}\text { Sagnalist, hugarflug með leiðsögn } \\
\text { (e. guided imagery), leikræn tjáning, } \\
\text { myndræn tjáning, skrifleg tjáning, } \\
\text { ritun }\end{array}$ & $\begin{array}{l}\text { Vekja til umhugsunar - efla } \\
\text { innsæi, skapandi hugsun og } \\
\text { tjáningu - virkja nemendur }\end{array}$ \\
\hline 6. Prautalausnir & $\begin{array}{l}\text { Rökprautir og heilabrjótar, } \\
\text { prautalausnir, hlutverkaleikir, } \\
\text { hermileikir. }\end{array}$ & $\begin{array}{l}\text { Vekja til umhugsunar - pjálfa } \\
\text { hugsun og ályktunarhæfni - } \\
\text { innsæi }\end{array}$ \\
\hline 7. Leitaraðferðir & $\begin{array}{l}\text { Rannsóknarverkefni, } \\
\text { spurningakannanir, vettvangsathuganir, } \\
\text { viðtöl, gagnagreining, tilraunir, } \\
\text { efnis- og heimildakönnun, } \\
\text { áhugasviðsverkefni, lausnaleitarnám }\end{array}$ & $\begin{array}{l}\text { Fræða - virkja nemendur - pjálfa } \\
\text { nemendur í að afla upplýsinga, } \\
\text { vinna úr peim og draga af peim } \\
\text { ályktanir }\end{array}$ \\
\hline $\begin{array}{l}8 . \\
\text { Hópvinnubrögð }\end{array}$ & $\begin{array}{l}\text { Hópverkefni, samvinnunám, } \\
\text { púslaðferðir (e. jigsaw), efniskönnun (e. } \\
\text { project) í vinnuhópum }\end{array}$ & $\begin{array}{l}\text { Efla sjálfstæð vinnubrögð og } \\
\text { samvinnu - verkaskipting - } \\
\text { upplýsingaöflun - úrvinnsla - } \\
\text { miðlun }\end{array}$ \\
\hline $\begin{array}{l}\text { 9. Sjálfstæð, } \\
\text { skapandi } \\
\text { viðfangsefni }\end{array}$ & $\begin{array}{l}\text { Demanám, sviðsetningarverkefni, } \\
\text { söguaðferðin (e. storyline), raunveruleg } \\
\text { viðfangsefni, pátttöku- og pjónustunám } \\
\text { (e. service learning) }\end{array}$ & $\begin{array}{l}\text { Stuðla að frumkvæði og } \\
\text { sjálfstæðum vinnubrögðum - frjó } \\
\text { og skapandi hugsun - nýsmíði - } \\
\text { hugmyndavinna - miðlun }\end{array}$ \\
\hline
\end{tabular}

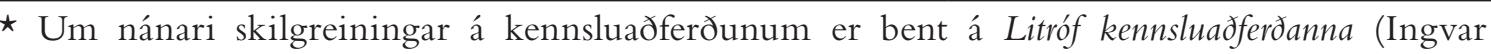
Sigurgeirsson, 2013)

Sú nálgun sem beitt var við próun líkansins er ólík peirri sem liggur til grundvallar flokkunarkerfunum sem lýst var hér að framan, sérstaklega peirri sem byggð er að mestu leyti á kenningum um nám (Joyce o.fl., 2015) og kalla mætti kenningastýrða nálgun (e. top-down approach). Dó að Litrófskerfið hafi próast út frá athugunum á flokkunarkerfum byggist pað öðrum præði á vettvangsathugunum. Dví má segja að par sé beitt gagnastýrðri nálgun (e. bottom-up approach) til að búa til flokkunarkerfi. Detta sést glöggt á umræðu höfundar um álitamál um flokkun tiltekinna aðferða sem sást beitt við kennslu (Ingvar Sigurgeirsson, 2013). Til viðbótar má benda á pað sérstaka álitamál hvort hafa eigi hópvinnubrögð sem sérstakan flokk kennsluaðferða eins og gert er í pessu líkani. 
Dau flokkunarkerfi sem hér er fjallað um eiga pó margt sameiginlegt og í mörgum tilvikum mætti fella flokka í Litrófinu beint undir tiltekna flokka í kenningaflokkuninni (til dæmis falla umræðu- og spurnaraðferðir undir hugræna kenningarammann og pulunám og pjálfunaræfingar undir atferliskenningarammann). Eins geta ákveðnir flokkar í Litrófskerfinu fallið beint undir annaðhvort kennarastýrðar aðferðir (til dæmis útlistunarkennsla, pulunám og pjálfunaræfingar) eða nemendamiðaðar (til dæmis leitaraðferðir, hópvinnubrögð og sjálfstæð, skapandi viðfangsefni). Í grófum dráttum má segja að flokkarnir níu í Litrófskerfinu raðist á ás frá kennarastýrðum til nemendamiðaðra aðferða.

Par sem eitt af markmiðum greiningarinnar er að skoða notagildi Litrófskerfisins er mikilvægt að hafa í huga hvernig kerfið varð til, pað er að pað var að hluta til unnið með hliðsjón af vettvangsathugunum í grunnskólum. Áhugavert er að skoða hvernig petta íslenska kerfi, sem einn af höfundum greinarinnar bjó til á sínum tíma, reynist á fleiri skólastigum og hér er sjónum beint að gildi slíkrar flokkunar á kennsluaðferðum í framhaldsskólum.

\section{Rannsóknir á kennsluaðferðum í framhaldsskólum}

Rannsóknirákennsluháttum víða um heim benda til pess að algengustu kennsluaðferðirá unglingaog framhaldsskólastigi falli í flokk kennarastýrðra aðferða, svo sem fyrirlestrar, sýnikennsla og vinna með námsbækur (sem á ensku er gjarnan kennt við seatwork). Nemendamiðaðar aðferðir virðast hafa átt undir högg að sækja, pó áhersla sé gjarnan lögð á pær í námskrám og handbókum (Bolinger og Warren, 2007; Braičić, Đuranović og Klasnić, 2014; Hackling, Goodrum og Rennie, 2001; Juuti, Lavonen, Uitto, Byman og Meisalo, 2010; Öztürk, 2011).

Fáar íslenskar rannsóknir veita beina innsýn í starfið í kennslustofum framhaldsskólanna með vettvangslýsingum en mikilvægar vísbendingar má fá úr rannsóknum sem byggjast á viðtölum við kennara. Í rannsóknarverkefninu Starfshæettir í framhaldsskólum voru til dæmis tekin viðtöl við nokkra tugi kennara. Í forrannsókn tóku Ârný Helga Reynisdóttir og Ingólfur Ásgeir Jóhannesson (2013) viðtöl við 12 reynda kennara sem töldu að kennsluhættir hefðu breyst, til dæmis kom fram hjá sumum viðmælendum að pað sem peir kölluðu „,verkefnavinnu“ og ,símat“ hefði aukist á kostnað prófa. Einnig gátu Árný og Ingólfur pess að tilkoma upplýsingatækni virtist hafa haft áhrif á kennsluna. Elsa Eiríksdóttir og Ingólfur Ásgeir Jóhannesson (2016) byggðu greiningu sína á viðtölum við 12 kennara í stærðfræði og verkgreinum og voru niðurstöðurnar ápekkar í pví að hlutfall verkefna í námsmati hefði aukist og að upplýsingatækni væri fyrirferðarmeiri í kennslunni, bæði í kennslustofunum og utan peirra.

Dær rannsóknir sem gerðar hafa verið í framhaldsskólum hér á landi og byggjast á vettvangsathugunum hafa annaðhvort beinst að einstökum árgangi framhaldsskólans eða að ákveðnum námsgreinum. Gerður G. Óskarsdóttir (2012) fylgdist með kennslu í 61 klukkustund á fyrsta ári í níu framhaldsskólum á haustönn 2008. Algengustu kennsluađferđirnar pá 13 daga sem vettvangsathuganir fóru fram voru fyrirlestrar og útskýringar kennara, að meðtöldu myndbandsáhorfi (43\% tímans). Nemendur glímdu við einstaklingsverkefni priðjung tímans (34\%), ýmist bókleg eða verkleg, og um 10\% tímans unnu nemendur að hópverkefnum.

Svanhildur Kr. Sverrisdóttir (2014) fylgdist með 87 kennslustundum í íslensku í fjórum framhaldsskólum og 56 kennslustundum í 8.-10. bekk í jafnmörgum grunnskólum á árunum 2010-2011. Hún lýsir kennsluaðferðum í framhaldsskólum með pessum orðum: „Annaðhvort hlustuðu nemendur á kennara eða samnemendur fjalla um viðfangsefni sem var á kennsluáætlun eða unnu verkefni í tengslum við viðfangsefni, ýmist einir eða með öðrum nemendum“ (bls. 122-123). Hafdís Ingvarsdóttir (2004, 2011) rannsakaði kennslu og viðhorf 12 enskukennara, meðal annars með viðtölum og vettvangsathugunum, í pví augnamiði að skoða að hvaða marki kennarar hefðu lagað kennslu sína að nýjum kröfum og hugmyndum um tungumálakennslu. Niðurstaða hennar var að námsbækur réðu mestu um uppbyggingu kennslunnar. Engu að síður beittu kennarar margvíslegum kennsluaðferðum og nýttu sér para-, hóp- og einstaklingsvinnu en nemendurnir réðu litlu um pað hvaða kennsluaðferðir urðu fyrir valinu. Eyrún María 
Rúnarsdóttir og Sigrún Aðalbjarnardóttir (2003) athuguðu hvort bekkjarumræður í 17 kennslustundum í lífsleikni og íslensku beindust að pví að örva og laða fram hugsun nemenda, mismunandi sjónarmið peirra og fá pá til að rökstyðja mál sitt og taka afstöðu til mála. Svo reyndist vera hjá lífsleiknikennaranum en mjög lítið í íslenskutímunum. Hliðstæðar niðurstöður koma fram í tveimur úttektum á vegumsað hefur verið til er ekkum.ið. En pær eru ta við nokkra tugi kennara og mennta- og menningarmálaráðuneytisins, pað er í íslensku (Svanhildur Kr. Sverrisdóttir, Ragnheiður Margrét Guðmundsdóttir og Sigurlína Davíðsdóttir, 2011) par sem fylgst var með 94 kennslustundum, og í stærðfræði (Anna Helga Jónsdóttir o.fl., 2014) par sem fylgst var meðal annars með kennslustundum og gerð úttekt á kennsluáætlunum og fleiri gögnum í níu ólíkum framhaldsskólum í premur völdum áföngum. Mjög algengt form kennslustundar, sem lýst var í báđum úttektunum, var að kennarar kenndu frá töflu í fyrri hluta kennslustundar en nemendur unnu að verkefnum í síðari hluta stundarinnar, gjarna pannig að kennarinn gengi á milli nemenda og aðstoðaði pá eftir pörfum. Dó kom fram í báðum úttektunum að nokkrar stundir hefðu byggst á meiri tilraunastarfsemi.

Dessar rannsóknir sem hér hefur verið sagt frá gefa pá mynd að kennsluaðferðir í framhaldsskólum séu langoftast kennarastýrðar og nemendur fremur óvirkir pótt mikilvægar undantekningar séu frá pví. Đótt niðurstöðurnar séu ekki einhlítar pá benda pær ekki til mikillar fjölbreytni. Hafa verður í huga að allar rannsóknirnar voru afmarkaðar við ákveðnar greinar eða misseri og gefa pví ekki neins konar yfirlit yfir pað hvaða kennsluaðferðum framhaldsskólakennarar beita, en pað er eitt af markmiðum pessarar rannsóknar. [1]

\section{Rannsóknarspurningar}

Markmið greinarinnar er sem fyrr segir tvípætt. Annars vegar er ætlunin að bregða upp yfirliti yfir kennsluaðferðir í framhaldsskólum. Vettvangsathuganir sem safnað var í rannsókninni Starfshæettir i framhaldsskólum gefa tækifæri til að skoða kennsluaðferðir almennt, par sem fylgst var með 130 kennslustundum í ólíkum kennslugreinum í níu mismunandi skólum. Í fyrri rannsóknum hefur athygli verið beint að tilteknum námsgreinum eða námsárum og úrtök verið minni. Hér er pví tækifæri til að bregða upp víðari mynd af peim aðferðum sem framhaldsskólakennarar beita við kennslu og einnig skoða hvaða aðferðir peir nota í ólíkum námsgreinum og á mismunandi námsgreinasviðum. Settar eru fram eftirfarandi rannsóknarspurningar:

1. Hvaða kennsluaðferðum beittu kennarar í 130 kennslustundum í framhaldsskólum og hvaða aðferðir reyndust vera algengastar?

2. Eru ólíkar kennsluaðferðir notaðar eftir námsgreinum og námsgreinasviðum?

Hins vegar er markmiðið að leggja matá notagildi Litrófskerfisins við greiningu á kennsluaðferðum á framhaldsskólastigi. Dví er einnig sett fram rannsóknarspurningin:

3. Hvernig reynist pað líkan sem sett er fram í Litrófi kennsluaðferðanna við flokkun kennsluaðferða í 130 kennslustundum í framhaldsskólum?

\section{Aðferð}

\section{Gögn}

Notað var gagnasafn úr rannsókninni Starfshettir i framhaldsskólum sem gerð var 2013-2014. [2] Gögnum var safnað í níu ólíkum framhaldsskólum sem valdir voru með lagskiptu slembiúrtaki eftir gerð (menntaskólar, fjölbrautaskólar, iðnskólar), stærð, landshlutum, aldri skóla eða pví hvort skólar hefðu nýlega gert róttækar breytingar á starfinu. Með pessu móti taldi rannsóknarhópurinn að náðst hefði nokkuð vel utan um fjölbreytni framhaldsskólanna.

Athugendur skráđu ítarlegar vettvangslýsingar í 130 kennslustundum sem voru valdar pannig að óskað var eftir pví að fá að fylgja stundaskrá bekkjar eða nemanda úr hverjum árgangi 
viðkomandi skóla. Dregin voru út af handahófi nöfn bekkja eða nemenda til að fylgja yfir skóladaginn (án vitundar nemendanna sem fylgt var). Reynt var að dreifa vettvangsathugunum á ólíkar námsbrautir og pví var í sumum tilvikum beitt hentivali við val kennslustunda til að tryggja sem mesta fjölbreytni.

Einn til tveir rannsakendur sátu hverja kennslustund. Kennslustund er hér skilgreind sem sú eining sem skóli hafði ákveðið að væri ein heild og kennari skipulagði pannig, jafnvel pótt í sumum tilvikum væru frímínútur teknar meðan á stundinni stóð. Rannsakendurnir skrádu ítarlegar upplýsingar um stundina, meðal annars um kennsluaðferðir, samskipti kennara og nemenda, framkomu kennara, námsgögn og miðla, upplýsingatækni og ástundun nemenda. Einnig var skrásett nákvæm tímalína um athafnir kennara og nemenda í sérstaka dálka á stöðluðu skráningarformi. Samtals var fylgst með kennslu í 167 klukkustundir og er pví meðallengd hvers áhorfs 83 mínútur. Stysta stundin sem fylgst var með var 27 mínútur en sú lengsta fjórar klukkustundir og 24 mínútur. Um 82\% stundanna voru á bilinu 40-80 mínútur.

Við flokkun stundanna í námsgreinaflokka komu upp margvísleg álitamál. Einfalt reyndist til dæmis að ákveða hvaða kennslustundir féllu undir íslensku og erlend tungumál. Meira álitamál var flokkun félagsvísindagreina sem undir falla til dæmis félagsfræði og lífsleikni en einnig viðskiptagreinar; niðurstaðan varð sú að bókfærsla yrði ekki höfð í flokki félagsvísindagreina par sem kennsluaðferðir par póttu skera sig úr öðrum greinum í flokknum.

\section{Greining}

Degar rannsakendur höfðu heimsótt skólana skráðu peir auk vettvangslýsinganna ýmsar upplýsingar um aðstæður í kennslustofunum (og öðrum kennslurýmum), fjölda nemenda, kennsluaðferðir og fleira í par til gerðan gagnagrunn. Degar höfundar greinarinnar hófu undirbúning að greiningunni byrjuðu peir á að skoða vettvangslýsingarnar en síðan skiptu peir peim á milli sín pannig að minnst tveir fóru vandlega yfir hverja lýsingu og skráđu ítarlegar viðbótarupplýsingar um kennsluaðferðir í gagnagrunninn. [3] Í framhaldi af pví var leitast við að greina kennsluaðferðirnar með hliðsjón af skilgreiningum í Litrófi kennsluaðferðanna (Ingvar Sigurgeirsson, 2013) og aðferðirnar síðan flokkaðar eftir Litrófskerfinu.

Við greininguna purfti að bregðast við nokkrum álitamálum. Í Litrófi kennsluaðferðanna er til dæmis hvergi að finna lýsingu á peirri kennsluaðferð pegar nemendur reikna dæmi og var peirri aðferð bætt við og hún felld undir flokk pjálfunaræfinga og skriflegra verkefna. Đá koma próf ekki við sögu sem kennsluaðferð í bókinni og voru pau felld í sérstakan flokk annarra aðferða sem búinn var til. Í Litrófi kennsluaðferðanna eru vettvangsathuganir taldar með leitaraðferðum en vettvangsferð, sem farin var í jarðfræðitíma í einum skólanna, sýndi vel að pað getur verið álitamál par sem hún byggðist jöfnum höndum á leiðsögn kennara, sýnikennslu, hópvinnu og náttúruskoðun og var með hliðsjón af pví ákveðið að fella vettvangsferðir í flokk með öðrum aðferðum. Aðeins ein kennslustund reyndist vera skráð með peim hætti að ekki tókst að greina hvaða kennsluaðferð var beitt. Í framhaldi af flokkuninni var tíðni einstakra aðferða skráð.

\section{Styrkleikar og veikleikar gagnasafnsins}

Meginstyrkleiki gagnasafnsins liggur í pví hversu ítarlegar og efnismiklar vettvangslýsingarnar eru. Lýsingarnar skráđu alls 15 rannsakendur en til að auka gæði peirra sátu reyndir rannsakendur og nemendur í doktors- og meistaranámi saman í 44\% tilvikanna og skráðu. Deir sameinuðu síðan skráningarnar í eina frásögn. Auk pess skiptust rannsakendur á að vinna saman og álitamál um skráninguna voru rædd jafnóðum á fundum rannsóknarhópsins. Fjöldi rannsakenda reyndist bæði vera styrkleiki og veikleiki; veikleiki vegna pess að samræmi, sérstaklega til að byrja með, var ekki alltaf til staðar, en styrkleiki par sem framkvæmd athugana var rækilega rædd á fundum rannsóknarhópsins. Pá ber pess að geta að skráningareyðublaðið hafði verið forprófað í tíunda skólanum. 
Tveir af höfundum greinarinnar skrádu lýsingar í fimm og sjö af skólunum hvor en einn höfundanna tók ekki pátt í gagnaöfluninni. Pað reyndist vera kostur par sem hinar skráðu lýsingar urðu að standa fyrir sínu. Skráning og frumúrvinnsla var ekki gerð eftir Litrófskerfinu heldur varð pað fyrir valinu eftir að rannsakendur úr hópnum höfðu leitað til höfundar pess með úrvinnslu af pessum toga úr gagnasafninu.

Hafa verður í huga pegar yfirlit er gefið um kennsluaðferðir að pótt um 130 stundir sé að ræða er petta ekki stórt úrtak úr allri kennslu í framhaldsskólum og fylgst var með fáum stundum í sumum námsgreinum svo að pað takmarkar alhæfingargildi. Рað skiptir pó miklu máli að framhaldsskólastarf sé rannsakað og pví hefur rannsókn sem pessi ótvírætt gildi.

\section{Niðurstöður}

Fyrst verður gefið yfirlit yfir tíðni allra kennsluaðferða sem greindar voru í vettvangslýsingunum og síðan fjallað um kennsluaðferðir í einstökum námsgreinum og á mismunandi greinasviðum.

\section{Tíðni kennsluaðferða í 130 kennslustundum}

Alls voru skráðar 22 tilgreindar kennsluaðferðir í kennslustundunum 130. Á töflu 2 er yfirlit sem sýnir hversu oft hverri aðferð var beitt.

Tafla 2. Tíðni 22 kennsluaðferða í 130 kennslustundum og hlutfall af bæði heild kennslustunda (130) eða kennsluaðferða (231). Um skilgreiningar á einstökum kennsluaðferðum er vísað í Litróf kennsluaðferðanna (Ingvar Sigurgeirsson, 2013).

\begin{tabular}{lccc}
\hline Kennsluaðferð & Tíðni & $\begin{array}{c}\text { Hlutfall (\%) } \\
\text { kennslustunda }\end{array}$ & $\begin{array}{c}\text { Hlutfall (\%) } \\
\text { kennsluaðferða }\end{array}$ \\
\hline Fyrirlestrar & 63 & $48 \%$ & $27 \%$ \\
Skrifleg verkefni & 31 & $24 \%$ & $13 \%$ \\
Hópvinna & 21 & $16 \%$ & $9 \%$ \\
Verklegar æfingar & 18 & $14 \%$ & $8 \%$ \\
Kvikmyndasýning & 16 & $12 \%$ & $7 \%$ \\
Nemendur reikna & 15 & $12 \%$ & $7 \%$ \\
Efnis- og heimildakönnun & 12 & $9 \%$ & $5 \%$ \\
Sjálfstæð, skapandi verkefni & 9 & $7 \%$ & $4 \%$ \\
Umræður & 8 & $6 \%$ & $3 \%$ \\
Lesið, spurt og spjallað & 6 & $7 \%$ & $3 \%$ \\
Námsleikir & 5 & $4 \%$ & $2 \%$ \\
Próf (tekin eða undirbúin) & 5 & $4 \%$ & $2 \%$ \\
Skapandi ritun & 5 & $4 \%$ & $1 \%$ \\
Leiksýning & 3 & $2 \%$ & $1 \%$ \\
Vettvangsferðir & 3 & $2 \%$ & $1 \%$ \\
Sýnikennsla & 2 & $2 \%$ & $1 \%$ \\
Djálfunaræfingar & 2 & $2 \%$ & $1 \%$ \\
Tilraunir & 2 & $2 \%$ & $2 \%$ \\
Aððferðir sem koma fyrir einu sinni & & & $\mathbf{1 0 0 \%}$ \\
hver (leikræn tjáning, prautalausn, & 5 & $4 \%$ & \\
spurningakönnun, vinnustofa, óljós aðferð) & & $\mathbf{1 0 0} \%$ & \\
\hline Samtals & $\mathbf{2 3 1}$ & & \\
\hline
\end{tabular}


Eins og sjá má voru fyrirlestrar algengasta kennsluaðferðin; peir voru notaðir í um pað bil annarri hverri kennslustund. Taka verður fram að margir fyrirlestranna falla í flokk gagnvirkra fyrirlestra, раð er kennarar brutu pá upp með spurningum eða umræðum. Aðrir voru gjarnan brotnir upp með kvikmyndasýningum eða verkefnum. Margir fyrirlestranna voru studdir glærum og nokkrir byggðust á töflukennslu, pað er kennarinn skráði útskýringar á töflu eða teiknaði par myndir til skýringar.

Sú kennsluaðferð sem var næstmest notuð er skrifleg verkefni. Dá koma hópverkefni en pau voru af ýmsum toga og voru flest peirra efniskönnunarverkefni par sem nemendur unnu að upplýsingaöflun, en einnig smærri úrlausnarefni.

Mynd 1 sýnir dreifingu kennsluaðferðanna pegar pær hafa verið flokkaðar eftir Litrófskerfinu. Eins og sjá má eru tveir kennsluaðferðaflokkar í aðalhlutverki: útlistunarkennsla annars vegar og pjálfunaræfingar og skrifleg verkefni hins vegar en kennsluaðferðir í pessum tveimur flokkum voru $61 \%$ peirra kennsluaðferða sem taldar voru. Niðurstöðurnar sýna að algengt mynstur í uppbyggingu kennslustunda er: kennari reifar, útskýrir eða kynnir tiltekið efni og 1 framhaldi vinna nemendur verkefni sem pví tengist.

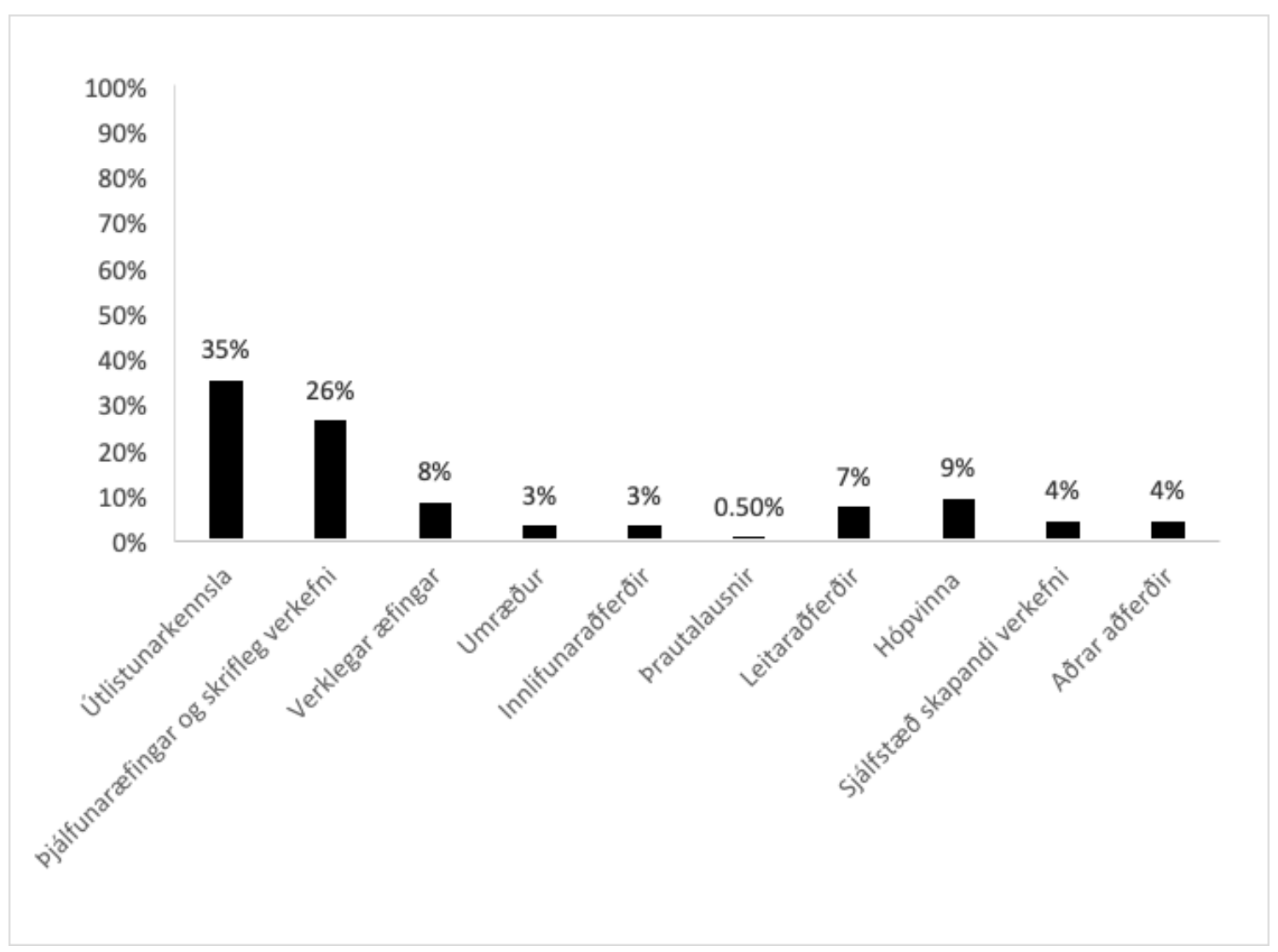

Mynd 1. Kennsluaðferðirnar flokkaðar eftir flokkunarkerfi í Litrófi kennsluaðferðanna.

Hér hefur verið greint frá pví hvaða kennsluaðferðir komu fram í kennslustundunum 130, en val á kennsluaðferðum er oft mismunandi eftir námsgreinum. Dví er mikilvægt að skoða kennsluaðferðir innan námsgreina sérstaklega. Hér verður fyrst fjallað um svokallaðar kjarnagreinar samkvæmt aðalnámskrá framhaldsskóla: íslensku, stærðfræði og ensku (önnur erlend tungumál eru tekin með í pann flokk). Eftir pað er fjallað um aðra greinaflokka í stafrófsröð, pað er félagsvísindagreinar, hugvísindagreinar, iðn- og starfsnámsgreinar og náttúruvísindagreinar. Loks er fjallað um kennsluaðferðir í peim námsgreinum par sem færri vettvangslýsingar voru til. 


\section{Kennsluaðferðir í íslensku}

Fylgst var með 12 kennslustundum í íslensku og mátti greina í peim 10 tilgreindar kennsluaðferðir sem komu alls fyrir 22 sinnum, pað er fleiri en einni kennsluaðferð var beitt í mörgum kennslustundum. Dær skiptast eftir Litrófskerfinu eins og sýnt er í töflu 3.

Tafla 3. Yfirlit yfir pær 22 kennsluaðferðir sem greindar voru í 12 kennslustundum í íslensku. Í töflunni kemur fram tíðni hvers kennsluaðferðarflokks, hlutfall af tíðni kennsluaðferða, um hvaða kennsluaðferðir innan flokksins var að ræða og hlutfall kennslustunda sem kennsluaðferðir komu fyrir í.

\begin{tabular}{lcccc}
\hline $\begin{array}{l}\text { Kennsluaðferða- } \\
\text { flokkur }\end{array}$ & $\begin{array}{c}\text { Tíðni } \\
\text { alls }\end{array}$ & $\begin{array}{c}\text { Hlutfall } \\
\text { kennsluaðferða }\end{array}$ & $\begin{array}{c}\text { Kennsluaðferðir } \\
\text { innan flokks }\end{array}$ & $\begin{array}{c}\text { Hlutfall } \\
\text { kennslustunda }\end{array}$ \\
\hline Útlistunarkennsla & 5 & $23 \%$ & $\begin{array}{c}\text { Fyrirlestrar (4) } \\
\text { Kvikmynd (1) }\end{array}$ & $33 \%$ \\
$\begin{array}{l}\text { Pjálfunaræfingar } \\
\text { og skrifleg verkefni }\end{array}$ & 5 & $23 \%$ & $\begin{array}{c}\text { Skrifleg verkefni (3) } \\
\text { Lesið, spurt og spjallað (2) }\end{array}$ & $8 \%$ \\
Verklegar æfingar & 0 & $0 \%$ & 0 & $17 \%$ \\
Umræður & 2 & $9 \%$ & 2 & $0 \%$ \\
Innlifunaraðferðir & 1 & $5 \%$ & 1 & $17 \%$ \\
Drautalausnir & 0 & $0 \%$ & 0 & $8 \%$ \\
Leitaraðferðir & 2 & $9 \%$ & Efniskönnun (2) & $17 \%$ \\
Hópvinna & 5 & $23 \%$ & 5 & $43 \%$ \\
$\begin{array}{l}\text { Sjálfstæð, skapandi } \\
\text { verkefni }\end{array}$ & 1 & $5 \%$ & 1 & $8 \%$ \\
Aðrar aðferðir & 1 & $5 \%$ & Próf (1) & $8 \%$ \\
\hline
\end{tabular}

Flestar kennsluaðferðirnar féllu í prjá flokka: útlistunarkennslu, pjálfunaræfingar og skrifleg verkefni og hópvinnu. Aðrar kennsluaðferðir komu sjaldnar fyrir, en umræður komu fyrir tvisvar og leitaraðferðir einnig tvisvar. Hvað varðar leitaraðferðir unnu nemendur að heimildaverkefni í öðru tilvikinu en skiluðu niðurstöðum í hinu. Í einni kennslustund fengust nemendur við sjálfstæett, skapandi verkefni sem byggðist á pví að peir áttu að undirbúa kennslu á sjálfvöldu efni.

Eins og sjá má gæetir pó nokkurrar fjölbreytni í útfærslu íslenskutímanna. Enda pótt kennslustundirnar séu aðeins 12 dreifast kennsluaðferðirnar á marga flokka og hlutur kennsluaðferða sem krefjast mikils framlags nemenda (nemendamiðaðar aðferðir) er umtalsverður.

\section{Kennsluaðferðir í stærðfræði}

Fylgst var með 14 kennslustundum í stærðfræði og mátti greina í peim sjö tilgreindar kennsluaðferðir sem komu fyrir 27 sinnum samtals. Pær skiptast eftir Litrófskerfinu eins og sýnt er í töflu 4. 
Tafla 4. Yfirlit yfir pær 27 kennsluaðferðir sem greindar voru í 14 kennslustundum í stærðfræði.

\begin{tabular}{lcccc}
\hline $\begin{array}{l}\text { Kennslu- } \\
\text { aðferðaflokkur }\end{array}$ & Tíðni & $\begin{array}{c}\text { Hlutfall } \\
\text { kennsluaðferða }\end{array}$ & $\begin{array}{c}\text { Kennsluaðferðir } \\
\text { innan flokks }\end{array}$ & $\begin{array}{c}\text { Hlutfall } \\
\text { kennslustunda }\end{array}$ \\
\hline $\begin{array}{l}\text { Útlistunarkennsla } \\
\text { bjálfunaræfingar og } \\
\text { skrifleg verkefni }\end{array}$ & 11 & $41 \%$ & $\begin{array}{c}\text { Fyrirlestrar } \\
\text { Nemendur reikna }\end{array}$ & $79 \%$ \\
Verklegar æfingar & 0 & $37 \%$ & & $71 \%$ \\
Umræður & 0 & $0 \%$ & & $0 \%$ \\
Innlifunaraðferðir & 1 & $0 \%$ & Leikræn tjáning & $7 \%$ \\
Drautalausnir & 1 & $4 \%$ & & $7 \%$ \\
Leitaraðferðir & 1 & $4 \%$ & Spurningakönnun & $7 \%$ \\
Hópvinna & 2 & $7 \%$ & & $14 \%$ \\
Sjálfstæð, skapandi & 0 & $0 \%$ & & $0 \%$ \\
verkefni & & $4 \%$ & Próf & $7 \%$ \\
Aðrar aðferðir & 1 & & & \\
\hline
\end{tabular}

Algengustu aðferðirnar í stærðfræði falla annars vegar undir útlistunarkennslu og hins vegar undir pjálfunaræfingar og skrifleg verkefni. Útlistunarkennslan byggðist í öllum tilvikum á fyrirlestrum við töflu par sem kennarinn útskýrði dæmi eða útreikninga, stundum með pátttöku nemenda. Pjálfunaræfingar og skrifleg verkefni fólust í útreikningum nemenda.

Eina skráđa tilvikið í kennslustundunum 130 um leikræna tjáningu var í stærðfræði en pá beitti kennari peirri aðferð sem kennd hefur verið við kennara í hlutverki (Anna Jeppesen, 1994, bls. 30-42). Kennarinn setti á sig hárkollu til að undirstrika hlutverk sitt sem dómari í keppni á milli nemenda um bestu úrlausn tiltekins verkefnis.

Flestar stærðfræðikennslustundirnar fylgdu líku mynstri; kennarinn útskýrði í upphafi stundarinnar dæmi eða aðferðir og síðan tóku nemendur til við að reikna, oftast einir, en máttu stundum hafa með sér samvinnu. Á töflu 5 má sjá uppbyggingu kennslustundanna 14. Eins og sjá má skáru prjár kennslustundir sig frá pví meginmynstri sem að öđru leyti var á kennslustundum í stærðfræði. 
Tafla 5. Röð kennsluaðferða í 14 kennslustundum í stærðfræði.

\begin{tabular}{|c|c|c|c|}
\hline $\begin{array}{l}\text { Kennslu- } \\
\text { stund }\end{array}$ & $\begin{array}{c}\text { Fyrsta } \\
\text { kennsluadferð }\end{array}$ & $\begin{array}{c}\text { Önnur } \\
\text { kennsluaðferð }\end{array}$ & $\begin{array}{c}\text { Driðja } \\
\text { kennsluaðferð }\end{array}$ \\
\hline 1 & Fyrirlestur (töflukennsla) & & \\
\hline 2 & Fyrirlestur (töflukennsla) & Nemendur reikna & \\
\hline 3 & Fyrirlestur (töflukennsla) & Nemendur reikna & \\
\hline 4 & Nemendur reikna (paravinna) & Nemendur reikna & Próf (undirbúningur) \\
\hline 5 & Fyrirlestur (töflukennsla) & Spurningakönnun & Hópverkefni \\
\hline 6 & Fyrirlestur (gagnvirkur) & Prautalausn & $\begin{array}{c}\text { Leikræn tjáning } \\
\text { (kennarinn í hlutverki) }\end{array}$ \\
\hline 7 & Fyrirlestur (töflukennsla) & $\begin{array}{l}\text { Nemendur reikna } \\
\text { (einstaklingsverkefni, } \\
\text { frjáls samvinna) }\end{array}$ & \\
\hline 8 & $\begin{array}{l}\text { Hópverkefni (nemendur } \\
\text { reikna) }\end{array}$ & & \\
\hline 9 & Fyrirlestur (frá töflu) & Nemendur reikna & \\
\hline 10 & Fyrirlestur (töflukennsla) & Nemendur reikna & \\
\hline 11 & Fyrirlestur (töflukennsla) & Nemendur reikna & \\
\hline 12 & Nemendur reikna & & \\
\hline 13 & Fyrirlestur (töflukennsla) & & \\
\hline 14 & Fyrirlestur (töflukennsla) & Nemendur reikna & \\
\hline
\end{tabular}

\section{Kennsluaðferðir í erlendum tungumálum}

Fylgst var með 20 kennslustundum í erlendum málum; níu kennslustundum í ensku, sex í dönsku, fjórum í pýsku og einni í frönsku. Alls mátti greina níu tilgreindar kennsluaðferðir og komu pær fyrir 37 sinnum samtals (sjá töflu 6). Eins og sjá má á töflunni falla flestar kennsluaðferðirnar undir flokk pjálfunaræfinga og skriflegra verkefna. Útlistunarkennsla og hópvinna voru næstalgengustu flokkarnir. 
Tafla 6. Yfirlit yfir pær kennsluaðferðir sem greindar voru í 20 kennslustundum í erlendum tungumálum.

\begin{tabular}{lcccc}
\hline $\begin{array}{l}\text { Kennslu- } \\
\text { aðferðaflokkur }\end{array}$ & $\begin{array}{c}\text { Tíðni } \\
\text { alls }\end{array}$ & $\begin{array}{c}\text { Hlutfall } \\
\text { kennsluaðferða }\end{array}$ & $\begin{array}{c}\text { Kennsluaðferðir } \\
\text { innan flokks }\end{array}$ & $\begin{array}{c}\text { Hlutfall } \\
\text { kennslustunda }\end{array}$ \\
\hline Útlistunarkennsla & 6 & $16 \%$ & Fyrirlestrar (4) & $20 \%$ \\
Kvikmynd (2) & $10 \%$ \\
$\begin{array}{l}\text { Pjálfunaræfingar og } \\
\text { skrifleg verkefni }\end{array}$ & 23 & $62 \%$ & $\begin{array}{c}\text { Skriflegar æfingar (12) } \\
\text { Námsleikir (5) }\end{array}$ & $60 \%$ \\
& & & Lesið, spurt og spjallað (4) & $25 \%$ \\
& & & Djálfunaræfingar (2) & $10 \%$ \\
Verklegar æfingar & 0 & $0 \%$ & 0 & $0 \%$ \\
Umræður & 0 & $0 \%$ & 0 & $0 \%$ \\
$\begin{array}{l}\text { Innlifunaraðferðir } \\
\text { Prautalausnir }\end{array}$ & 2 & $5 \%$ & Ritun (2) & $10 \%$ \\
Leitaraðferðir & 0 & $0 \%$ & & $0 \%$ \\
Hópvinna & 2 & $5 \%$ & Efniskönnun (2) & $10 \%$ \\
Sjálfstæð, skapandi & 0 & $11 \%$ & 4 & $20 \%$ \\
verkefni & $0 \%$ & 0 & $0 \%$ \\
Aðrar aðferðir & 0 & $0 \%$ & 0 & $0 \%$ \\
\hline
\end{tabular}

Athygli er vakin á pví að við fyrstu sýn virðast niðurstöðurnar benda til einsleitni hvað kennsluaðferðir varðar í erlendum málum par sem flestar aðferðirnar falla í einn flokk kennsluaðferða og fimm flokkar komu ekkert við sögu. Detta er pó ekki alls kostar réttmætt par sem í flokki pjálfunaræfinga eru margar ólíkar kennsluaðferðir, meðal annars námsleikir, en allir námsleikir sem skráđir voru í rannsókninni tengdust kennslu erlendra mála. Uppbygging kennslustunda í erlendum málum var oft fjölbreytt, eins og hér má sjá dæmi um pegar rannsakandi lýsti kennslustund í erlendu máli í hnotskurn.

Rifjaður var upp orðaforði úr textum sem lesnir hafa verið á önninni ... nemendur unnu saman í hópum við að para saman útklippt orð á ensku og íslensku. Pegar allir höfðu parað saman orðin fóru fulltrúar úr hverjum hópi í annan hóp til pess að athuga hvort orðin í peim hópi væru rétt pöruð saman. Kennari sýndi svo nemendum rétt svör á glæru. Síðan var rifjaður upp orðaforði úr texta sem nemendur lásu í síðasta tíma. ... Degar pessu var lokið unnu nemendur verkefni sem tengist textanum sem peir lásu í síðasta tíma. Deir svöruðu spurningum úr textanum á íslensku. Loks unnu peir annað verkefni sem tengdist sama texta en pað var orðaforðaverkefni par sem tengja átti stök orð við rétta merkingu (orðin voru útskýrð á ensku). Nemendur svöruðu spurningunum í pörum en unnu tengiverkefnið í stærri hópum. Deir hjálpuðust að ef peir skildu ekki orðin og báðu um hjálp kennara ef enginn í hópnum pekkti merkingu viðkomandi orðs. (Lýsing rannsakenda á kennslustund í hnotskurn).

\section{Kennsluaðferðir í félagsvísindagreinum}

Fylgst var með 17 kennslustundum í félagsvísindagreinum, par af 11 í félagsfræði (prjár peirra voru í kynjafræði), prjár í sálfræði (ein peirra var ípróttasálfræði) og einni á hverju eftirfarandi sviða: vímuefnafræðslu, uppeldisfræði og lífsleikni. Alls voru skráðar átta ólíkar kennsluaðferðir í pessum 17 stundum, alls 36 sinnum samtals. Dær skiptast eftir Litrófskerfinu eins og sýnt er í töflu 7. 
Tafla 7. Yfirlit yfir pær kennsluaðferðir sem greindar voru í 17 kennslustundum í félagsvísindagreinum.

\begin{tabular}{lcccc}
\hline $\begin{array}{l}\text { Kennslu- } \\
\text { aðferðaflokkur } \\
\text { Útlistunarkennsla }\end{array}$ & $\begin{array}{c}\text { Tíðni } \\
\text { alls }\end{array}$ & $\begin{array}{c}\text { Hlutfall } \\
\text { kennsluaðferða }\end{array}$ & $\begin{array}{c}\text { Kennsluaðferðir } \\
\text { innan flokks } \\
\text { Fyrirlestar (10) }\end{array}$ & $\begin{array}{c}\text { Hlutfall } \\
\text { kennslustunda }\end{array}$ \\
$\begin{array}{l}\text { Kjálfunaræfingar og } \\
\text { skrifleg verkefni }\end{array}$ & 6 & $44 \%$ & $59 \%$ \\
$\begin{array}{l}\text { Verklegar æfingar } \\
\text { Umræður }\end{array}$ & 0 & $0 \%$ & 0 & $29 \%$ \\
Innlifunaraðferðir & 3 & $9 \%$ & 3 & $0 \%$ \\
& 3 & $9 \%$ & Leiksýning (2) & $12 \%$ \\
Prautalausnir & 0 & $0 \%$ & Ritun (1) & $6 \%$ \\
Leitaraðferðir & 3 & $9 \%$ & 0 & $0 \%$ \\
Hópvinna & 4 & $12 \%$ & Efniskönnun & $18 \%$ \\
Sjálfstæð, skapandi & 0 & $0 \%$ & 4 & $24 \%$ \\
verkefni & & & 0 & $0 \%$ \\
Aðrar aðferðir & 0 & $0 \%$ & & 0 \\
\hline
\end{tabular}

Flestar aðferðirnar falla í flokk útlistunarkennslu og voru fyrirlestrar algengastir en kvik-myndir voru einnig algengar. Pjálfunaræfingar og skrifleg verkefni voru næstalgengasti flokkurinn og hópvinna kom par á eftir.

Til innlifunaraðferða er talinn undirbúningur tveggja leikhúsferða og eitt ritunarverkefni í sálfræðitíma. Ritunarverkefnið fólst í pví að nemendur áttu að velta fyrir sér eigin sjálfsmynd og pví sem hefði mótað hana. Til leitaraðferða eru talin prjú efniskönnunarverkefni en pau voru í raun fleiri par sem prjú af peim fjórum hópverkefnum sem voru skráð byggðust einnig á efniskönnun.

Í félagsvísindagreinum voru prír af peim átta umræðutímum sem skráđir voru í kennslustundunum 130. Í einum peirra var notuð tiltekin samræðuaðferð (e. questioning strategy) sem var aðeins skráð tvívegis samtals í gagnasafninu. Í pessari kennslustund studdist kennarinn við aðferð sem kennd hefur verið við loftvog (Ingvar Sigurgeirsson, 2016) og talin er henta vel í umræðum um álitamál:

Kennsluaðferðir eru kynning (20 mín.) og umræður (50 mín.) sem kennari hefur skipulagt nákvæmlega áður; er með spurningu sem á að ræða: „Er æskilegt/óæskilegt að hafa upptöku-myndavélar í kennslustofum í [skóla]?“ Kennari biður nemendur að taka afstöðu til spurningarinnar og raða sér síðan í stofuna samkvæmt afstöðu, ýmist aftast, fremst eða í miðju. Nemendur mjög virkir í umræðunni. (Lýsing rannsakanda á kennslustund í hnotskurn.)

\section{Kennsluaðferðir í hugvísindagreinum}

Fylgst var með 11 kennslustundum sem falla undir hugvísindagreinar (í greinum öðrum en tungumálum), pað er níu í sögu, einni í heimspeki og einni í siðfræði. Skráðar voru átta tilteknar kennsluaðferðir og komu pær fyrir samtals 21 sinni. Pær skiptast eftir Litrófskerfinu eins og sýnt er í töflu 8. 
Tafla 8. Yfirlityfirpærkennsluaðferðirsem greindarvoruí11 kennslustundumíhugvísindagreinum.

\begin{tabular}{|c|c|c|c|c|}
\hline $\begin{array}{l}\text { Kennslu- } \\
\text { aðferdaflokkur }\end{array}$ & $\begin{array}{c}\text { Tíðni } \\
\text { alls }\end{array}$ & $\begin{array}{c}\text { Hlutfall } \\
\text { kennsluaðferða }\end{array}$ & $\begin{array}{c}\text { Kennsluaðferðir } \\
\text { innan flokks }\end{array}$ & $\begin{array}{c}\text { Hlutfall } \\
\text { kennslustunda }\end{array}$ \\
\hline \multirow[t]{2}{*}{ Útlistunarkennsla } & 10 & $48 \%$ & Fyrirlestar (8) & $73 \%$ \\
\hline & & & Kvikmynd (2) & $18 \%$ \\
\hline $\begin{array}{l}\text { Djálfunaræfingar og } \\
\text { skrifleg verkefni }\end{array}$ & 3 & $14 \%$ & 3 & $27 \%$ \\
\hline Verklegar afingar & 0 & $0 \%$ & 0 & $0 \%$ \\
\hline Umræður & 1 & $5 \%$ & 1 & $9 \%$ \\
\hline Innlifunaraðferðir & 1 & $5 \%$ & Ritun (1) & $9 \%$ \\
\hline Drautalausnir & 0 & $0 \%$ & 0 & $0 \%$ \\
\hline Leitaraðferðir & 2 & $10 \%$ & Efniskönnun (2) & $18 \%$ \\
\hline Hópvinna & 2 & $10 \%$ & 2 & $18 \%$ \\
\hline Sjálfstæð, skapandi verkefni & 0 & $0 \%$ & 0 & $0 \%$ \\
\hline Aðrar aðferðir & 2 & $10 \%$ & Vettvangsferðir (2) & $18 \%$ \\
\hline
\end{tabular}

Flest tilvikin falla í flokk útlistunarkennslu en segja má að hér gæti nokkurrar fjölbreytni prátt fyrir pað pví aðrar kennsluaðferðir dreifast nokkuð á flokka. Leitaraðferðaverkefnin tvö sem fylgst var með tengdust bæði sögukennslu. Í öðru tilvikinu voru nemendur að afla sér upplýsinga um sögustaði sem til stóð að heimsækja í tengslum við vettvangsferð. Í hinu voru nemendur að leggja síðustu hönd á sjálfstæett heimildaverkefni í Íslandssögu sem peir kynntu skólafélögum sínum og studdust m.a. við vefsíður, veggspjöld. kynningarforrit og kvikmyndir. Í framhaldi af kynningunum var jafningjamat par sem stuðst var við matskvarða.

\section{Kennsluaðferðir í iðn- og starfsnámsgreinum}

Fylgst var með 19 kennslustundum sem féllu undir starfsnámsgreinar, bæði verklegum tímum, bóknámstímum og blönduðum tímum. Alls voru taldar 27 kennsluaðferðir í pessum tímum sem skiptust eins og sjá má á töflu 9. 
Tafla 9. Yfirlit yfir pær kennsluaðferðir sem greindar voru í 19 kennslustundum í iðn- og starfsnámsgreinum.

\begin{tabular}{lcccc}
\hline $\begin{array}{l}\text { Kennsluaðferða- } \\
\text { flokkur }\end{array}$ & $\begin{array}{c}\text { Tíðni } \\
\text { alls }\end{array}$ & $\begin{array}{c}\text { Hlutfall } \\
\text { kennsluaðferða }\end{array}$ & $\begin{array}{c}\text { Kennsluaðferðir } \\
\text { innan flokks }\end{array}$ & $\begin{array}{c}\text { Hlutfall } \\
\text { kennslustunda }\end{array}$ \\
\hline $\begin{array}{l}\text { Útlistunarkennsla } \\
\begin{array}{l}\text { pjálfunaræfingar og } \\
\text { skrifleg verkefni }\end{array}\end{array}$ & 9 & $33 \%$ & Fyrirlestrar & $47 \%$ \\
$\begin{array}{l}\text { Verklegar æfingar } \\
\text { Umræður }\end{array}$ & 9 & $15 \%$ & $\begin{array}{c}\text { Nemendur reikna (2) } \\
\text { Skrifleg verkefni (2) }\end{array}$ & $11 \%$ \\
Innlifunaraðferðir & 1 & $43 \%$ & 9 & $47 \%$ \\
Drautalausnir & 0 & $0 \%$ & 1 & $5 \%$ \\
Leitaraðferðir & 0 & $0 \%$ & 0 & $0 \%$ \\
Hópvinna & 0 & $0 \%$ & 0 & $0 \%$ \\
$\begin{array}{l}\text { Sjálfstæð, skapandi } \\
\text { verkefni }\end{array}$ & 3 & $11 \%$ & 0 & $0 \%$ \\
Annað & 1 & $4 \%$ & 3 & $16 \%$ \\
\hline
\end{tabular}

Flestar aðferðirnar falla í tvo flokka, útlistunarkennslu og verklegar æfingar. Verklegu æfingarnar sem skráđar voru í kennslustundum í starfsnámsgreinum eru helmingur allra slíkra tilvika sem skráð voru í rannsókninni.

Athyglisverður er flokkur sjálfstæðra, skapandi viðfangsefna par sem nemendur unnu að stórum, raunhæfum verkefnum. Í einu tilvikinu fólst pað í pví að undirbúa tiltekinn rekstur, í öðru að undirbúa tiltekinn viðburð og í hinu priðja að hanna og smíða tiltekinn grip.

\section{Kennsluaðferðir í náttúruvísindagreinum}

Alls var fylgst með 18 kennslustundum í náttúruvísindagreinum. Sjö kennslustundanna voru í eðlis- eða efnafræði, fimm í líffræði, prjár í jarðfræði og ein kennslustund í eftirfarandi: Landafræði, náttúruvísindum (inngangsnámskeið) og umhverfisfræði. Alls var skráð 31 kennsluaðferð í pessum 18 kennslustundum, sjá töflu 10. 
Tafla 10. Yfirlit yfir pær kennsluaðferðir sem greindar voru í 18 kennslustundum í náttúruvísindagreinum.

\begin{tabular}{|c|c|c|c|c|}
\hline $\begin{array}{l}\text { Kennslu- } \\
\text { aðferðaflokkur }\end{array}$ & $\begin{array}{c}\text { Tídni } \\
\text { alls }\end{array}$ & $\begin{array}{c}\text { Hlutfall } \\
\text { kennsluaðferða }\end{array}$ & $\begin{array}{c}\text { Kennsluaðferðir } \\
\text { innan flokks }\end{array}$ & $\begin{array}{c}\text { Hlutfall } \\
\text { kennslustunda }\end{array}$ \\
\hline \multirow[t]{3}{*}{ Útlistunarkennsla } & 14 & $45 \%$ & Fyrirlestrar (11) & $61 \%$ \\
\hline & & & Kvikmynd (2) & $11 \%$ \\
\hline & & & Sýnikennsla (1) & $6 \%$ \\
\hline \multirow{2}{*}{$\begin{array}{l}\text { Djálfunaræfingar og } \\
\text { skrifleg verkefni }\end{array}$} & 6 & $19 \%$ & Nemendur reikna (3) & $16 \%$ \\
\hline & & & Skrifleg verkefni (3) & $16 \%$ \\
\hline Verklegar æfingar & 1 & $3 \%$ & 1 & $6 \%$ \\
\hline Umræður & 0 & $0 \%$ & 0 & $0 \%$ \\
\hline Innlifunaraðferðir & 0 & $0 \%$ & 0 & $0 \%$ \\
\hline Drautalausnir & 0 & $0 \%$ & 0 & $0 \%$ \\
\hline Leitaraðferðir & 2 & $6 \%$ & Tilraunir (2) & $11 \%$ \\
\hline Hópvinna & 5 & $16 \%$ & 5 & $28 \%$ \\
\hline $\begin{array}{l}\text { Sjálfstæð, skapandi } \\
\text { verkefni }\end{array}$ & 0 & $0 \%$ & 0 & $0 \%$ \\
\hline \multirow[t]{3}{*}{ Aðrar aðferðir } & & $10 \%$ & Próf (1) & $6 \%$ \\
\hline & & & Vettvangsferð (1) & $6 \%$ \\
\hline & & & Óljóst^ (1) & $6 \%$ \\
\hline
\end{tabular}

* Ekki var unnt að ráða af vettvangslýsingu hvaða kennsluaðferð var beitt.

Flestar kennsluaðferðirnar í náttúruvísindagreinum falla í flokk útlistunarkennslu og oftast var um að ræða fyrirlestra (sem yfirleitt voru gagnvirkir) pótt tvisvar væri sýnd kvikmynd, og í einni stundinni var sýnikennsla. Sýnikennslan var í jarðfræðitíma par sem kennari sýndi nemendum ýmsar stein- og bergtegundir. Djálfunaræfingar og skrifleg verkefni voru næstalgengasti flokkurinn og fólust í helmingi tilvika í útreikningum. Hópverkefni voru leyst í fimm stundum og voru prjú peirra efniskönnunarverkefni (pau gætu líka fallið í flokk leitaraðferða). Í tveimur kennslustundum fengust nemendur við tilraunir sem falla í flokk leitaraðferða og í einni var verkleg æfing, en pað var smásjárskoðun í líffræðitíma.

Prjár kennsluaðferðir eru taldar í flokki annarra kennsluaðferða; í einu tilviki undirbjuggu nemendur sig fyrir próf, önnur aðferðin var vettvangsferð og hin priðja var einstaklingsverkefni sem nemendur unnu í framhaldi af fyrirlestri. Í vettvangsferðinni söfnuðu nemendur bergsýnum í nærliggjandi fjallshlíð, greindu pau og flokkuðu í litlum hópum.

Degar litið er yfir kennsluaðferðirnar í náttúruvísindagreinunum vekur athygli hve lítill heildarhlutur verklegra æfinga og tilrauna er. Útlistunarkennsla var oftast 1 a đalhlutverki, ásamt skriflegum verkefnum.

\section{Kennsluaðferðir í öðrum greinum og pverfaglegum áföngum}

Fylgst var með 20 kennslustundum í nokkrum námsgreinum sem ekki falla undir flokkana sem gerð hefur verið grein fyrir hér að framan og eiga pað einnig sameiginlegt að athuganir náðu aðeins til fárra kennslustunda. Detta eru fimm ípróttatímar, fjórir tölvufræðitímar, fjórir sjónlistatímar og fjórir tímar par sem fengist var við pverfagleg viðfangsefni. Loks er einn bókfærslutími, ein kennslustund í frumkvöðlamennt og einn „opinn“ tími (vinnustofa) par sem nemendur fengust við viðfangsefni sem tengdust ýmsum námsgreinum. Tafla 11 sýnir 31 kennsluaðferð sem taldar voru í pessum 20 kennslustundum. 
Vart parf að taka fram að pað er álitamál hvort eðlilegt sé að flokka pessar stundir úr ólíkum greinum saman. Dær eru pó pað hátt hlutfall heildarstundanna að óeðlilegt væri að sleppa peim úr greiningunni. Í pessum stundum er til dæmis að finna helming allra peirra verklegu æfinga sem skráðar voru í kennslustundunum 130 og tæpan helming af peim sjálfstæðu, skapandi verkefnum sem skráð voru.

Tafla 11. Yfirlit yfir pær kennsluaðferðir sem greindar voru í 20 kennslustundum í nokkrum ólíkum námsgreinum og pverfaglegum áföngum.

\begin{tabular}{|c|c|c|c|c|}
\hline $\begin{array}{l}\text { Kennslu- } \\
\text { aðferðaflokkur }\end{array}$ & $\begin{array}{c}\text { Tídni } \\
\text { alls }\end{array}$ & $\begin{array}{c}\text { Hlutfall } \\
\text { kennsluaðferða }\end{array}$ & $\begin{array}{l}\text { Kennsluaðferðir } \\
\text { innan flokka }\end{array}$ & $\begin{array}{c}\text { Hlutfall } \\
\text { kennslustunda }\end{array}$ \\
\hline \multirow[t]{3}{*}{ Útlistunarkennsla } & 11 & $35 \%$ & Fyrirlestrar (6) & $30 \%$ \\
\hline & & & Kvikmynd (4) & $20 \%$ \\
\hline & & & Sýnikennsla (1) & $5 \%$ \\
\hline \multirow{2}{*}{$\begin{array}{l}\text { Djálfunaræfingar og } \\
\text { skrifleg verkefni }\end{array}$} & 2 & $8 \%$ & Nemendur reikna (1) & $5 \%$ \\
\hline & & & Skrifleg verkefni (1) & $5 \%$ \\
\hline Verklegar æfingar & 9 & $19 \%$ & 9 & $45 \%$ \\
\hline Umræður & 1 & $4 \%$ & 1 & $5 \%$ \\
\hline Innlifunaraðferðir & 1 & $4 \%$ & Ritun (1) & $5 \%$ \\
\hline Drautalausnir & 0 & $0 \%$ & 0 & $0 \%$ \\
\hline Leitaraðferðir & 0 & $0 \%$ & 0 & $0 \%$ \\
\hline Hópvinna & 2 & $8 \%$ & 2 & $10 \%$ \\
\hline $\begin{array}{l}\text { Sjálfstæð, skapandi } \\
\text { verkefni }\end{array}$ & 4 & $15 \%$ & 4 & $20 \%$ \\
\hline \multirow[t]{2}{*}{ Aðrar aðferðir } & 2 & $8 \%$ & Próf (1) & $5 \%$ \\
\hline & & & Vinnustofa (1) & $5 \%$ \\
\hline
\end{tabular}

Í pessum kennslustundum fór mikið fyrir útlistunarkennslu, eins og í fleiri flokkum, og voru pað fyrirlestrar og kvikmyndasýningar. Verklegar æfingar voru næstalgengasti flokkurinn og par á eftir sjálfstæð, skapandi verkefni.

Dau fjögur skipti par sem nemendur fengust við sjálfstæð, skapandi verkefni voru pessi: Í frumkvöðlamennt par sem nemendur leystu nýsköpunarverkefni, eitt verkefnið tengdist sjónlistum og tvö pverfaglegum áföngum. Hér er lýsing rannsakanda á kennslustund par sem nemendur fást fyrst við skapandi ritun en síðan við sjálfstætt, skapandi viðfangsefni.

Kennslustundin hófst á [kynningu á nýju verkefni]. Detta er verkefni sem nemendur geta gripið til pegar peir hafa skilað öðrum verkefnum til að fylla upp í annars dauðan tíma. Um er að ræða skapandi verkefni sem tengist [nokkrum námsgreinum]. Lögð var áhersla á að verkefnið sé fræðandi og skapandi. Eftir innlögn kennara héldu nemendur áfram að vinna ritunarverkefni ... Deir áttu að skila verkefninu í lok kennslustundarinnar.Verkefnið er „skapandi skrif“. Nemendur áttu að semja sögu og áttu peir að flétta málshætti og orðtök inn í sögurnar. Nemendur unnu verkefnin í tölvum og kennari gekk á milli og svaraði spurningum nemenda. Hann reyndi að leiða nemendur áfram, t.d. pegar peir spurðu um merkingu málshátta reyndi hann að leiða pá að svarinu með pví að spyrja spurninga. Detta er einstaklingsverkefni. Deir sem voru búnir að skila ritunarverkefninu áttu að byrja á verkefninu sem kynnt var í byrjun kennslustundarinnar. Deir máttu vinna saman tveir til prír eða einir. Detta er verkefni sem nemendur hafa mjög frjálsar hendur með. Deir geta notað hvaða aðferð sem peir vilja til að koma upplýsingum til skila, t.d. myndband, plaköt eða dans. Áhersla var lögð á að verkefni peirra pyrftu að vera fræðandi. (Lýsing rannsakanda á kennslustund í hnotskurn.) 


\section{Samantekt á kennsluaðferðum í námsgreinum}

Í yfirliti um pað hvernig kennsluaðferðaflokkarnir birtast í námsgreinum og á námsgreinasviðum (sjá töflu 12) sést vel hve stór hlutur útlistunarkennslu, pjálfunaræfinga og skriflegra verkefna er í flestum námsgreinum og greinaflokkum. Kennsluaðferðir í pessum tveimur flokkum samanlagt eru meira en helmingur kennsluaðferða í flestum greinum. Undantekningarnar eru íslenska, starfsnámsgreinar og námsgreinar sem felldar voru undir aðrar námsgreinar.

Tafla 12. Yfirlit um dreifingu kennsluaðferðaflokka eftir námsgreinum og námsgreinasviðum. Hlutfall algengustu flokkanna er feitletrað.

\begin{tabular}{|c|c|c|c|c|c|c|c|c|}
\hline & Íslenska & $\begin{array}{l}\text { Stærð- } \\
\text { fræði }\end{array}$ & $\begin{array}{l}\text { Erlend } \\
\text { mál }\end{array}$ & $\begin{array}{l}\text { Félags- } \\
\text { vísinda- } \\
\text { greinar }\end{array}$ & $\begin{array}{c}\text { Hug- } \\
\text { vísinda- } \\
\text { greinar }\end{array}$ & $\begin{array}{l}\text { Starfs- } \\
\text { náms- } \\
\text { greinar }\end{array}$ & $\begin{array}{c}\text { Náttúru- } \\
\text { vísinda- } \\
\text { greinar }\end{array}$ & $\begin{array}{c}\text { Aðrar } \\
\text { náms- } \\
\text { greinar }\end{array}$ \\
\hline Útlistunarkennsla & $23 \%$ & $41 \%$ & $16 \%$ & $44 \%$ & $48 \%$ & $33 \%$ & $45 \%$ & $35 \%$ \\
\hline $\begin{array}{l}\text { Djálfunaræfingar } \\
\text { og skrifleg verkefni }\end{array}$ & $23 \%$ & $37 \%$ & $62 \%$ & $18 \%$ & $14 \%$ & $15 \%$ & $19 \%$ & $8 \%$ \\
\hline Verklegar æfingar & $0 \%$ & $0 \%$ & $0 \%$ & $0 \%$ & $0 \%$ & $33 \%$ & $3 \%$ & $19 \%$ \\
\hline Umræður & $9 \%$ & $0 \%$ & $0 \%$ & $9 \%$ & $5 \%$ & $4 \%$ & $0 \%$ & $4 \%$ \\
\hline Innlifunaraðferðir & $5 \%$ & $4 \%$ & $5 \%$ & $9 \%$ & $5 \%$ & $0 \%$ & $0 \%$ & $4 \%$ \\
\hline Prautalausnir & $0 \%$ & $4 \%$ & $0 \%$ & $0 \%$ & $0 \%$ & $0 \%$ & $0 \%$ & $0 \%$ \\
\hline Leitaraðferðir & $9 \%$ & $4 \%$ & $5 \%$ & $9 \%$ & $10 \%$ & $0 \%$ & $6 \%$ & $0 \%$ \\
\hline Hópvinna & $23 \%$ & $7 \%$ & $11 \%$ & $12 \%$ & $10 \%$ & $0 \%$ & $16 \%$ & $8 \%$ \\
\hline $\begin{array}{l}\text { Sjálfstæð, skapandi } \\
\text { verkefni }\end{array}$ & $5 \%$ & $0 \%$ & $0 \%$ & $0 \%$ & $0 \%$ & $11 \%$ & $0 \%$ & $15 \%$ \\
\hline Aðrar aðferðir & $5 \%$ & $4 \%$ & $0 \%$ & $0 \%$ & $10 \%$ & $4 \%$ & $10 \%$ & $8 \%$ \\
\hline
\end{tabular}

\section{Umræður}

Markmið greinarinnar var tvípætt: Annars vegar að bregða upp yfirliti yfir kennsluaðferðir í framhaldsskólum og hins vegar að leggja mat á notagildi líkansins við flokkun kennsluaðferða sem í pessari grein hefur verið kennt við Litrófskerfið.

\section{Einkenni og tíðni kennsluaðferða í framhaldsskólum}

Раð yfirlit sem hér hefur verið brugðið upp sýnir að langmest fer fyrir útlistunaraðferðum í kennslustundunum 130 og par næst pjálfunaræfingum og skriflegum verkefnum. Kennsluaðferðir í pessum tveimur flokkum sem falla undir kennarastýrðar aðferðir voru rúm $60 \%$ peirra aðferða sem framhaldsskólakennararnir beittu. Sé verklegum æfingum bætt hér við færist hlutfall kennarastýrðra aðferða nær 70\%. Hlutur kennarastýrðra eða beinna kennsluaðferða í kennslustundunum 130 er pví mjög afgerandi.

Dessar niðurstöður eru hliðstæðar niðurstöðum úr öðrum rannsóknum á kennsluháttum, bæði á albjóðlegum vettvangi (Bolinger og Warren, 2007; Braičić o.fl., 2014; Hackling o.fl., 2001; Juuti o.fl., 2010; Öztürk, 2011) og á Íslandi (Anna Helga Jónsdóttir o.fl., 2014; Gerður G. Óskarsdóttir, 2012; Hafdís Ingvarsdóttir 2004, 2011; Svanhildur Kr. Sverrisdóttir, 2014; Svanhildur Kr. Sverrisdóttir o.fl., 2011). Niðurstöður okkar gefa pó til kynna meiri fjölbreytni en fyrri hérlendar rannsóknir hafa gert. Enda pótt útlistunaraðferðir og skrifleg verkefni af ýmsu tagi séu fyrirferðarmestu aðferðirnar mátti sjá fjölda annarra aðferða. Rétt er pó að nefna að Hafdís Ingvarsdóttir (2004, 2011), sem rannsakaði enskukennslu 12 framhaldskólakennara, lagði áherslu á pað í niðurstöðum sínum að vettvangsathuganir staðfestu beitingu fjölbreyttra kennsluaðferða (para-, hóp- og einstaklingsvinnu) en hún benti jafnframt á að útfærslan væri öll á hendi kennara og undantekning ef nemendur fengju svigrúm til sjálfstæðra vinnubragða. Аð pessu leyti er meiri samhljómur milli rannsóknar okkar og Hafdísar. 
Dó að nokkurrar fjölbreytni gæti í niðurstöðum okkar hallar á pær aðferðir sem hvað mestar kröfur gera til nemenda um ákvarðanir, sjálfstæði, pátttöku og frumkvæði (sjá einnig Gerði G. Óskarsdóttur, 2018a). Pannig má álykta að í heild dugi kennsluaðferðirnar of skammt til pess „að nemendur öðlist margvíslega hæfni“, eins og aðalnámskrá framhaldsskóla gerir kröfur um (Mennta- og menningarmálaráðuneytið, 2011, bls. 29). Hér hljóta nokkur atriði að stinga í augu.

Í fyrsta lagi vekur athygli hve lítinn hlut samræður fá. Skipulegar umræður koma aðeins fyrir í átta kennslustundum af 130 og aðeins í tveimur er hægt að greina að beitt sé sérstakri spurnaraðferð. Í aðalnámskrá fyrir framhaldsskóla frá 2011 er mikil áhersla lögð á hæfni nemenda í tjáningu, miðlun og samræðum (bls. 36-37, 43-44 og víðar). Vandséð er að skilyrði hafi verið sköpuð til að proska pessa hæfni, gefi pessar niðurstöður réttar vísbendingar um umfang samræðna 1 framhaldsskólum.

Annað atriðið sem hér verður staldrað við er hversu sjaldan nemendur fá að glíma við rannsóknarverkefni með pví að beita leitaraðferðum, til dæmis að gera kannanir og tilraunir. Að vísu eru í gagnasafninu dæmi um að nemendur fengju að glíma við efniskannanir, en aðeins í tveimur tilvikum er skráð að peir hafi fengið að gera tilraunir. Segja má að aukin áhersla á verkleg viðfangsefni, ekki síst par sem nemendur setja sig í spor rannsakenda, hafi verið rauður práður í allri kennslufræði undanfarna öld (Helle, Tynjälä og Olkinuora, 2006; Krajcik og Blumenfeld, 2005) án pess pó að ná að festa rætur í skólastarfi.

Í priðja lagi má ræða hlut hópvinnunnar, en aðeins $9 \%$ kennsluaðferðanna reynast vera af pví tagi. Samvinna nemenda er stundum notuð sem páttur í öðrum kennsluaðferðum en engu að síður getur hlutur hennar ekki talist vera stór (sjá ítarlegri greiningu Gerðar G. Óskarsdóttur, 2018b). Í aðalnámskrá framhaldsskóla er undirstrikað að lykilhæfni feli meðal annars í sér að nemandi búi yfir „jákvæðri og uppbyggilegri félags- og samskiptahæfni“ (Mennta- og menningarmálaráðuneytið, 2011, bls. 25). Aðeins í einni kennslustund af kennslustundunum 130 mátti sjá að beitt væri samvinnunámsaðferð með skipulegum hætti. Rannsakendurnir veltu pessu talsvert fyrir sér meðan á gagnaöfluninni stóð og einn peirra skrifaði við eina vettvangslýsinguna: „Rannsakandi veltir fyrir sér hversu lítið skipulag er á hópavinnu almennt í framhaldsskólum landsins og lítil áhersla á að virkja alla með markvissum hætti ..." Detta er umhugsunarvert í pví ljósi að fjöldi rannsókna bendir til pess að vel skipulagt samvinnunám hafi ekki aðeins félagslegt gildi heldur stuðli einnig að góðum námsárangri og jákvæðum viðhorfum til náms (sjá til dæmis Gillies, 2016; Hänze og Berger, 2007; Waughan, 2002).

Enda pótt kennarastýrðar kennsluaðferðir séu viðamestar beittu kennarar fjölmörgum öðrum aðferðum, pótt í minni mæli væri. Hlutur nemendamiðaðra kennsluaðferða, svo sem hópverkefna, efniskönnunarverkefna, námsleikja og sjálfstæðra, skapandi verkefna, er pó ekki stór í sniðum og með hliðsjón af kröfum aðalnámskrár framhaldsskóla frá 2011 um fjölbreytni hlýtur að mega halda pví fram að sóknarfæri felist í pví að auka veg slíkra aðferða.

\section{Kennsluaðferðir eftir námsgreinum}

Talsverður munur kom fram á tíðni kennsluaðferða eftir námsgreinum. Mestrar fjölbreytni gætti í íslenskutímum sé miðað við að íslenskukennararnir sóttu aðferðir sínar í flesta flokka kennsluaðferða. Fábreyttasta kennslan, miðað við pær stundir sem hér voru skoðaðar, var hins vegar í stærðfræði. En minna verður á að í báðum tilvikum voru fremur fáar kennslustundir til skoðunar.

Niðurstöður um einsleitni kennsluaðferða í stærðfræði eru pó í samræmi við úttekt menntaog menningarmálaráðuneytisins á stærðfræðikennslu í framhaldsskólum (Anna Helga Jónsdóttir o.fl., 2014). Í tillögum sínum leggja höfundar úttektarinnar áherslu á að kennsla í stærðfræði megi „ekki einskorðast við að fara yfir lista tiltekinna efnisatriða eða staðlaðar reikniaðferðir“ og að í hæfniprepum í aðalnámskrá séu ,talin ... fjölmörg markmið varðandi skilning og hæfni til að beita stærðfræði ... og pau verða að vera í öndvegi í námi og kennslu“" (bls. 56). Hér er augljóslega 
hægt að auka fjölbreytni. Í aðalnámskrá framhaldsskóla er mikil áhersla á að nemendur fái að glíma við prautalausnaverkefni í stærðfræði (Mennta- og menningarmálaráðuneytið, 2011, bls. 69-72). Í pví gagnasafni sem gerð hefur verið grein fyrir í pessari grein er aðeins að finna eitt dæmi um slíkt verkefni.

Í rannsóknum á notkun kennsluaðferða eftir námsgreinum á háskólastigi hefur komið fram að kennarastýrðar aðferðir séu algengari i „, hörðum“ vísindum eins og stærðfræði og náttúruvísindum en nemendamiðaðar aðferðir líklegri innan „mýkri“ vísinda, svo sem félags- og hugvísinda (Lindblom-Ylänne o.fl., 2006; Lueddeke, 2003). Að einhverju marki má greina álíka niðurstöður hér pó pað gildi frekar um stærðfræði en náttúrufræðigreinar og fara verði varlega 1 ályktanir vegna takmarkaðs fjölda stunda í hverjum námsgreinaflokki. En komið hefur í ljós í viðtölum við kennara sem kenndu hluta peirra stunda sem um ræðir að kennarar telja erfiðara að kenna stærðfræði á fjölbreyttan hátt en náttúrufræði (Elsa Eiríksdóttir og Ingólfur Ásgeir Jóhannesson, 2016).

Degar á heildina er litið má greina ákveðin mynstur aðferða innan námsgreinaflokka, sem ekki ætti að koma á óvart, til dæmis um að pjálfunaræfingar voru algengar í erlendum tungumálum og verklegar æfinga í iðn- og starfsnámi. En einnig má í öllum flokkum sjá áhugaverð uppbrot og nýstárlegar nálganir í kennslu og pví er ljóst að pó námsgreinaflokkar geti sett mark sitt á kennsluaðferðir sem kennarar beita eru einnig mörg dæmi um kennara sem brjóta upp hefðir.

\section{Notagildi líkansins}

Annað meginmarkmið pessarar greinar var að skoða notagildi flokkunarlíkans fyrir kennsluaðferðir (Ingvar Sigurgeirsson, 2013), svokallaðs Litrófskerfis. Degar hefur verið vikið að nokkrum álitamálum um flokkun kennsluaðferða. Við beitingu Litrófskerfisins á gögnin kom fram sá augljósi veikleiki að höfundur bókarinnar hafði ekki séð ástæðu til að fjalla sérstaklega um pá algengu kennsluaðferð pegar nemendur reikna dæmi, til dæmis í stærðfræði eða náttúrugreinum. Auðsýnt er að bæta verði úr pessu.

Sérstakur vandi við umfjöllun um kennsluaðferðir og um leið flokkun peirra er að heiti kennsluaðferða og skilgreiningar á peim eru oft mjög á reiki, eins og gefin voru dæmi um hér fyrr í pessari grein. Taka mætti fjölmörg dæmi til viðbótar. Sú kennsluaðferð, sem kölluð er brainstorming á ensku, hefur fjölmörg heiti á íslensku, meðal annars, hugarflug, hugflæði, hugstormun, pankahríð og pankaregn. Og vel að merkja - pessi aðferð var hvergi skráð í kennslustundunum 130. Annað gott dæmi um petta er sú aðferð sem á ensku er kennd við project og höfundur Litrófs kennsluaðferðanna vildi kalla efniskönnun (eða efnis- og heimildakönnun). Pessi aðferð gengur undir fjölmörgum heitum, svo sem könnunaraðferð, verkefnadrifið nám, verkefnamiðað nám og verkefnavinna (síðastnefnda orðið getur einnig vísað til glímu nemenda við eyðufyllingarverkefni). Rannsóknarhópurinn glímdi við petta ósamkomulag um heiti kennsluaðferða í gagnaöfluninni og skráningunni í gagnagrunninn en höfundar pessarar greinar telja að peim hafi tekist að átta sig á flestum kennslustundanna hvað petta varðar.

Áleitnasti vandinn er líklega pegar kennsluaðferð getur gengið pvert á flokka eða pegar pær skarast milli flokka. Dæmi um pað eru fyrrnefnd efniskönnunarverkefni sem nemendur fást gjarnan við í hópvinnu. Á að flokka pau sem efniskönnunarverkefni eða hópverkefni (eins og gert var í rannsókninni)?

Í inngangi var sérstaklega vikið að pví álitamáli hvort líta ætti á hópvinnubrögð sem sérstakan flokk kennsluaðferða. Flest viðfangsefni sem lögð eru fyrir nemendur má væntanlega vinna ýmist einn, í pörum eða hópum. Dar sem flokkun kennsluaðferða í Litrófskerfinu er hugsuð með hliðsjón af markmiðum peirra má vissulega færa rök fyrir pví að hópvinnubrögð standi ekki undir nafni sem sjálfstæður kennsluaðferðaflokkur. Annað gildir um samvinnunámsaðferðir (e. cooperative learning, collaborative learning) par sem peim kennsluaðferðum er sérstaklega ætlað аð 
pjálfa nemendur í samvinnu. Dess er pví að vænta að við próun líkansins verði sérstaklega hugað að pessu.

Annað dæmi um álitamál við flokkun kennsluaðferða sem vert er að skoða eru aðferðir sem segja má að séu samsettar. Nefna má vettvangsferðina sem skrád var lýsing á; par komu í raun fyrir margar aðferðir; sýnikennsla, örfyrirlestrar og verklegar æfingar.

\section{Lokaorð}

Niðurstöður pessarar rannsóknar gefa til kynna að tveir flokkar kennsluaðferða séu langmest áberandi í flestum námsgreinum. Um leið sýna pær talsverða möguleika á pví að gera kennsluna fjölbreytilegri, til dæmis pannig að ef umræður voru í 9\% íslenskutíma og félagsvísindatíma, gætu umræður orðið umfangsmeiri hluti kennslunnar bæði í peim greinum og ýmsum öðrum. Баð vekur líka athygli að mest er um sjálfstæð, skapandi verkefni í peim kennslustundum sem felldar voru í flokk annarra námsgreina, en pær tengdust flestar pverfaglegum áföngum, ípróttum, sjónlistum og tölvufræði. Reynsluna af pvílíku skipulagi kennslu má notfæra sér í hefðbundnari greinum og útfæra pannig markmið aðalnámskrár um aukna fjölbreytni í kennslu til að stuðla að margvíslegri hæfni nemenda.

Flokkunarkerfi af pví tagi sem hér hafa verið rædd, svo sem Litrófsflokkunarkerfið, flokkunin í kennarastýrðar og nemendamiðaðar aðferðir og aðalflokka kennsluaðferða, sem Joyce og félagar hafa notað, eru í senn „fræðilegar æfingar“ og hagnýt tæki sem nýtast bæði starfandi kennurum og ekki síður kennaranemum til að átta sig á forsendum fjölbreytilegra kennsluaðferða og skyldleika peirra. En greiningin hér sýnir okkur vel að slík kerfi ná líklega aldrei fullkomlega utan um flókinn veruleika skólastofunnar.

\section{Aftanmálsgreinar}

1. Í pessari yfirferð höfum við ekki talið með úttektir gerðar í einstökum skólum, hvort sem pær voru gerðar á vegum mennta- og menningarmálaráðuneytisins eða annarra aðila, og ekki heldur meistaraprófsritgerðir nema efni peirra hafi birst í fræðigrein. Fæstar peirra eru byggðar á vettvangsathugunum í kennslustundum. Höfundum er kunnugt um tvær rannsóknir sem fóru fram samhliða peirri sem sagt er frá í pessari grein, byggðar á vettvangsathugunum, en niðurstöður urðu ekki tiltækar fyrr ef eftir að okkar grein hafði verið skrifuð. Sú fyrri er rannsóknin Íslenska sem námsgrein og kennslutunga par sem gerðar voru 56 vettvangslýsingar á 1. og 3. námsári í fimm framhaldsskólum (Kristján Jóhann Jónsson og Ásgrímur Angantýsson, 2018). Í peirri síðari gerði Súsanna Margrét Gestsdóttir myndbandsupptökur af sögukennslu í 54 kennslustundum í 12 framhaldsskólum (Súsanna Margrét Gestsdóttir, van Boxtel og van Drie, 2018).

2. Megingagnasöfnun í rannsókninni Starfshattir í framhaldsskólum fór fram á tímabilinu október 2013 til nóvember 2014 í níu framhaldsskólum, auk pess sem rannsóknartækin voru forprófuð í tíunda skólanum. Gögnin eru vettvangslýsingar á 130 kennslustundum, yfir 60 afrituð viðtöl við nemendur (hópviðtöl), kennara og stjórnendur, ljósmyndir úr kennslustofum, kennsluáæetlanir og önnur skrifleg gögn. Fimmtán manna hópur fræðafólks við Menntavísinda- og Félagsvísindasvið Háskóla Íslands tók pátt í gagnasöfnuninni. Rannsóknin naut styrkja úr Rannsóknarsjóði Háskóla Íslands á árunum 2013-2015 og frá Norræna öndvegissetrinu Justice Through Education in the Nordic Countries, styrktu af NordForsk, 2013-2018. Við pökkum sérstaklega framhaldsskólunum sem veittu aðgang að starfinu í rannsóknarskyni. Rannsóknargögnunum er nánar lýst í grein Gerðar G. Óskarsdóttur og rannsóknarhópsins (2018).

3. Við hina formlegu yfirferð til að skrá upplýsingar úr vettvangslýsingunum í gagnagrunn höfu höfundar samvinnu við Valgerði S. Bjarnadóttur sem var meðal rannsakendanna sem öfluðu gagnanna. En í reynd lásu höfundar greinarinnar ýmist allar vettvangslýsingarnar eða mikinn meirihluta peirra hver um sig. 


\section{Teaching methods in 130 lessons in upper secondary schools}

This article investigates the characteristics of the teaching methods used by Icelandic upper secondary school teachers across 130 lessons, exploring whether commonalities can be seen among the teaching methods employed in different subjects and subject groups. The authors present different models that have been used to categorize teaching methods, such as distinguishing between teacher- and student-centered methods, dividing them into different "families" (Joyce et al., 2015), according the theoretical background they derive from, or categorizing them by the similarity of their pedagogical approach, as is done in a model presented in an Icelandic handbook on teaching methods (Ingvar Sigurgeirsson, 1999, 2013) which was used to further analyze the lessons. The model classifies teaching methods into nine categories: (1) Expository methods, (2) recitation, drill, and practice, (3) hands on methods, (4) questioning strategies and discussions, (5) artistic and expressive methods, (6) problem solving, (7) inquiry methods, (8) group work and cooperative methods, and (9) student centered projects.

The 130 lesson observations were collected as part of the project Upper Secondary School Practices in Iceland, October 2013 to November 2014. Nine different upper secondary schools were selected from a stratified population, and the lessons were chosen in such a way that the sample would include lessons in all major subjects and a variety of other subjects. The lessons ranged from 27 minutes to roughly 4 hours, with the majority ranging from $40-80$ minutes. One, and in $44 \%$ of the cases, two researchers, out of the total of 15 researchers associated with the project, attended each lesson and produced a detailed written record of the activities. The researchers reported on various (previously agreed upon) aspects of each lesson, such as teaching methods, communication between teachers and students, the teachers' conduct and demeanor, use of teaching materials and media, information technology, and student classroom engagement and diligence. In analyzing the data, the resulting 130 written lesson protocols were read and reread for verification, the observed teaching methods categorized and other relevant information (e.g. number of students, nature of the classroom) entered into a database.

Firstly, the data were analyzed by subject, and secondly, as a whole, in order to identify all teaching methods used as well as the most common methods. The lessons attended were divided into eight different subjects and subject groups: Icelandic, mathematics, foreign languages, social sciences, humanities (other than languages), vocational studies, natural sciences, and, finally, a group with lessons where there were fewer than ten observations in each subject.

In the whole sample, two groups of methods; that is, expository methods, on the one hand, and recitation, drill, and practice, on the other, were by far most commonly seen and together comprised more than half of the teaching methods observed. The use of teaching methods varied by subject and subject group. The largest diversity of methods was seen in Icelandic and vocational studies, whereas mathematics lessons stood out for lack of diversity in the teaching methods employed.

To a degree, these results reflect prior research in the area, both international (Bolinger and Warren, 2007; Braičić et al., 2014; Hackling et al., 2001; Juuti et al., 2010; Öztürk, 2011) and Icelandic (Anna Helga Jónsdóttir et al., 2014; Gerður G. Óskarsdóttir, 2012; Hafdís Ingvarsdóttir 2004, 2011; Svanhildur Kr. Sverrisdóttir, 2014; Svanhildur Kr. Sverrisdóttir et al., 2011). However, the current results have the advantage of framing a large set of lessons from different schools where various subject groups can be scrutinized simultaneously for comparison. The results indicate a larger diversity in teaching methods used, compared to prior Icelandic studies 
at upper secondary school level, and despite the fact that expository methods and various seatwork assignments were found to be the most common approach, the data revealed that upper secondary school teachers employed a variety of different teaching methods.

It was notable how little role student-centered methods played in the lessons observed; that is, lessons requiring independent decision-making, participation, and student initiative. As a result, it is not likely that the teaching methods used in upper secondary schools in Iceland will help students develop the diverse competencies required by the national curriculum guide (Mennta- og menningarmálaráðuneytið [Ministry of Education, Science and Culture], 2011). Moreover, the results suggest that the use of approaches such as discussion, inquiry, and cooperative methods should be increased.

The model used for categorization proved helpful in analyzing the lessons, but less so when teachers employed combined or complex methods, showing the limits of any classification attempt. However, categorizing teaching methods in this manner has an important applied value for policy and teacher education, as well as furthering academic and practical discussion on teaching methods and their characteristics.

Key words: teaching methods, upper secondary school, teaching methods model

\section{Um höfundana}

Ingvar Sigurgeirsson (ingvar@hi.is) er prófessor við Menntavísindasvið Háskóla Íslands. Hann lauk kennaraprófi við Kennaraskóla Íslands 1970 og B.Ed.-prófi frá Kennaraháskóla Íslands 1985, meistaragráðu frá Háskólanum í Sussex 1986 og doktorsgrádu frá sama skóla 1992. Rannsóknir Ingvars hafa einkum snúist um námskrár, kennsluhætti, kennsluaðferðir, námsmat og skólapróun.

Elsa Eiríksdóttir (elsae@hi.is)er dósent við Menntavísindasvið Háskóla Íslands. Hún lauk BA-gráðu í sálfræði frá Háskóla Íllands 1999 og meistara- og doktorsprófi í verkfræðilegri sálfræði 2007 og 2011 frá Georgia Institute of Technology. Rannsóknir hennar hafa helst snúið að hugrænum ferlum í námi, yfirfærslu pekkingar og færni, verklegu námi og starfsnámi.

Ingólfur Ásgeir Jóhannesson (ingo@hi.is) er prófessor við Menntavísindasvið Háskóla Íslands. Hann lauk bakkalárprófi í sagnfræði og uppeldisfræði 1979, námi til kennsluréttinda 1980 og cand.mag.-prófi í sagnfræði 1983 frá Háskóla Íslands, og doktorsprófi í menntunarfræðum frá Wisconsinháskóla, Madison, 1991. Sérsvið hans eru námskrár, framhaldsskólar, menntastefna og kynjafræði í menntarannsóknum.

\section{About the authors}

Ingvar Sigurgeirsson (ingvar@hi.is) is á professor at the School of Education, University of Iceland. He acquired his teacher certificate from the College of Education in Iceland in 1970 and a B.Ed. degree from the University College of Education in 1985, an M.A. in Education from the University of Sussex in 1986 and a D.Phil. degree from the University of Sussex in 1992. His main research has been in the area of curriculum and instruction, teaching methods, assessment and school development.

Elsa Eiríksdóttir (elsae@hi.is) is an associate professor at the University of Iceland, School of Education. She completed a BA degree in psychology from the University of Iceland in 1999 and a Master's and a PhD in engineering psychology from Georgia Institute of Technology in Atlanta in 2007 and 2011, respectively. Her research interests include learning, transfer of training, skill acquisition, and vocational education and learning.

Ingólfur Ásgeir Jóhannesson (ingo@hi.is) is a professor at the School of Education, University of Iceland. He completed his BA degree in history and educational studies in 1979, a post-graduate diploma for a teaching certificate in 1980, a cand.mag. degree in history in 1983, all from the University of Iceland, and a $\mathrm{PhD}$ degree in curriculum and instruction from the University of Wisconsin in 1991. His research focuses on curriculum, upper secondary schools, education policy, and gender and education. 


\section{Heimildir}

Anna Jeppesen. (1994). Mál og túlkun. Handbók kennara. Reykjavík: Námsgagnastofnun.

Anna Helga Jónsdóttir, Eggert Briem, Freyja Hreinsdóttir, Freyr Pórarinsson, Jón Ingólfur Magnússon og Rögnvaldur Möller. (2014). Úttekt á sterðfreððikennslu í framhaldsskólum. Reykjavík: Mennta- og menningarmálaráðuneytið.

Anna Ólafsdóttir. (2014). Hugmyndir háskólakennara um „góda háskólakennslu“ og peettir innan og utan stofnunar sem peir telja að hafi áhrif á hvernig kennslan fer fram (óútgefin doktorsritgerð). Háskóli Íslands, Reykjavík.

Árný Helga Reynisdóttir og Ingólfur Ásgeir Jóhannesson. (2013). Fleiri vindar blása:Viðhorf reyndra framhaldsskólakennara til breytinga í skólastarfi 1986-2012. Netla-Veftímarit um uppeldi og menntun. Sótt af http://netla.hi.is/greinar/2013/ ryn/006.pdf

Bolinger, K. og Warren, W. J. (2007). Methods practiced in social studies instruction: A review of public school teachers' strategies. International Journal of Social Education, 22(1), 68-84. Sótt af https://eric.ed.gov/?id=EJ779674

Braičić, Z., Đuranović, M. og Klasnić, I. (2014). Teaching and learning methods and practices in science and social study lessons. Croatian Journal of Education, 17(1), 83-95. doi:10.15516/cje.v17i0.1524

Burden, P. R. og Byrd, D. M. (2016). Methods for effective teaching: Meeting the needs of all students. Boston: Pearson.

Elsa Eiríksdóttir og Ingólfur Ásgeir Jóhannesson. (2016). Sjónarmið stærðfræði- og verkgreinakennara í framhaldsskólum um hvaða öfl hafa áhrif á starfshætti: Námsmat og upplýsingatækni. Tímarit um uppeldi og menntun, 25(2), 2016, 197-218. Sótt af https://ojs.hi.is/tuuom/article/view/2435/1319

Eyrún María Rúnarsdóttir og Sigrún Aðalbjarnardóttir. (2003). „Ertu frjáls?““ Uppeldissýn og bekkjarumræður kennara. Í Friðrik H. Jónsson (ritstjóri), Rannsóknir í félagsvísindum IV: Félagsvísindadeild (bls. 245-255). Reykjavík: Félagsvísindastofnun Háskóla Íslands.

Gerður G. Óskarsdóttir. (2012). Skil skólastiga: Frá leikskóla til grunnskóla og grunnskóla til framhaldsskóla. Reykjavík: Háskólaútgáfan og Skóla- og frístundasvið Reykjavíkurborgar.

Gerður G. Óskarsdóttir. (2018a). Frumkvæði nemenda: Innlit í kennslustundir níu framhaldsskóla. Netla - veftímarit um uppeldi og menntun. Sérrit 2018 - Framhaldsskólinn í brennidepli. Menntavísindasvið Háskóla Íslands. Sótt af http://netla. hi.is/serrit/2018/framhaldskolinn_brennidepli/06.pdf

Gerður G. Óskarsdóttir. (2018b). Samvinna framhaldsskólanemenda: Liður í lærdómi til lýðræðis. Netla - veftímarit um uppeldi og menntun. Sérrit 2018 - Framhaldsskólinn í brennidepli. Menntavísindasvið Háskóla Íslands. Sótt af http://netla. hi.is/serrit/2018/framhaldskolinn_brennidepli/10.pdf

Gerður G. Óskarsdóttir og rannsóknarhópurinn. (2018). Starfshættir í framhaldsskólum: Aðdragandi og framkvæmd rannsóknar 2012-2018. Netla - veftímarit um uppeldi og menntun. Sérrit 2018 - Framhaldsskólinn í brennidepli. Mentnavísindasvið Háskóla Íslands. Sótt af http://netla.hi.is/serrit/2018/framhaldskolinn_brennidepli/01.pdf

Gillies, R. M. (2016). Cooperative learning: Review of research and practice. Australian Journal of Teacher Education, 41(3), 38-54. doi:10.14221/ajte.2016v41n3.3

Hackling, M. W., Goodrum, D. og Rennie, L. J. (2001). The state of science in Australian secondary schools. Australian Science Teachers Journal, 47(4), 6-17. Sótt af http://ro.ecu.edu.au/ecuworks/4682/

Hafdís Ingvarsdóttir. (2004). ,... ef pað er eitthvað sem peim pykir áhugavert.“ Enskukennsla við upphaf 21. aldar. Í Úlfar Hauksson (ritstjóri), Rannsóknir i félagsvísindum V (bls. 471-482). Reykjavík: Félagsvísindastofnun Háskóla Íslands.

Hafdís Ingvarsdóttir. (2011). Teaching English in a new age: Challenges and opportunities. Í B. Hudson og M. Meinert (ritstjórar), Beyond fragmentation: Didactics, learning and teaching in Europe (bls. 93-106). Opladen: Barbara Budrich Publishers.

Hattie, J. (2009). Visible learning: A synthesis of over 800 meta-analyses relating to achievement. London: Routledge.

Hänze, M. og Berger, R. (2007). Cooperative learning, motivational effects, and student characteristics: An experimental study comparing cooperative learning and direct instruction in 12th grade physics classes. Learning and Instruction, 17(1), 29-41. doi:10.1016/j.learninstruc.2006.11.004

Helle, L., Tynjälä, P. og Olkinuora, E. (2006). Project-based learning in post-secondary education - theory, practice and rubber sling shots. Higher Education, 51(2), 287-314. doi: 10.1007/s10734-004-6386-5

Ingvar Sigurgeirsson. (1992). The role, use and impact of curriculum materials in intermediate level Icelandic classrooms (óntgefin doktorsritgerð). University of Sussex, Brighton.

Ingvar Sigurgeirsson. (1994). Notkun námsefnis í 10-12 ára deildum grunnskóla og viððhorf kennara og nemenda til pess. Reykjavík: Rannsóknarstofnun Kennaraháskóla Íslands.

Ingvar Sigurgeirsson. (1999). Litróf kennsluaðferðanna. Handbók fyrir kennara. Reykjavík: Æskan.

Ingvar Sigurgeirsson. (2013). Litróf kennsluaðferdanna: Handbók fyrir kennara og kennaraefni (2. útgáfa). Reykjavík: Iðnú.

Ingvar Sigurgeirsson. (2016). Listin að spyrja. Reykjavík: Sögur útgáfa. 
Joyce, B., Calhoun, E. og Hopkins, D. (1997). Models of learning - tools for teaching. Buckingham: Open University Press. Joyce, B. og Weil, M. (1972). Models of teaching. Englewood Cliffs: Prentice-Hall.

Joyce, B., Weil, M. og Calhoun, E. (2015). Models of teaching (9. útgáfa). Boston: Pearson.

Joyce, B., Weil, M. og Showers, B. (1992). Models of teaching (4. útgáfa). Boston: Allyn and Bacon.

Juuti, K., Lavonen, J., Uitto, A., Byman, R. og Meisalo,V. (2010). Science teaching methods preferred by grade 9 students in Finland. International Journal of Science and Mathematics Education, 8(4), 611-632. Sótt af https://link.springer.com/ article/10.1007/s10763-009-9177-8

Kaplan, P. S. (1990). Educational psychology for tomorrow's teacher. St. Paul:West.

Krajcik, J. S. og Blumenfeld, P. C. (2005). Project-based learning. Í R. K. Sawyer (ritstjóri), The Cambridge handbook of the learning sciences (bls. 317-334). Cambridge: Cambridge University Press.

Kristján Jóhann Jónsson og Ásgrímur Angantýsson (ritstjórar). (2018). Íslenska í grunnskólum og framhaldsskólum. Reykjavík: Háskólaútgáfan.

Lemlech, J. K. (1994). Curriculum and instructional methods for the elementary and middle school. New York: Macmillan.

Lindblom-Ylänne, S., Trigwell, K., Nevgi, A. og Ashwin, P. (2006). How approaches to teaching are affected by discipline and teaching context. Studies in Higher Education, 31(3), 285-298. doi:10.1080/03075070600680539

Lueddeke, G. R. (2003). Professionalising teaching practice in higher education: A study of disciplinary variation and “teaching-scholarship". Studies in Higher Education, 28(2), 213-228. doi:10.1080/0307507032000058082

Mennta- og menningarmálaráđuneytið. (2011). Aðalnámskrá framhaldsskóla 2011: Almennur hluti. Reykjavík: Höfundur.

Mosston, M. og Ashworth, S. (1990). The spectrum of teaching styles: From command to discovery. New York: Longman.

Ornstein, A. C. (1990). Strategies for effective teaching. New York: Harper \& Row.

Schleicher, A. (2018). Valuing our teachers and raising their status. How communities can help. Paris: OECD. doi:10.1787/9789264292697-en

Shulman, L. S. (1986). Those who understand: Knowledge growth in teaching. Educational Researcher, 15(2), 4-14.

Stronge, J. H. og Xu, X. (2016). Instructional strategies for effective teaching. Bloomington: Solution Tree Press.

Súsanna Margrét Gestsdóttir, van Boxtel, C. og van Drie,J. (2018). Teaching historical thinking and reasoning: Construction of an observation instrument. British Educational Research Journal. doi:10.1002/berj.3471

Svanhildur Kr. Sverrisdóttir. (2014). Ef a a er gád: Afdrif aðalnámskrár i íslensku á unglingastigi grunnskóla og i framhaldsskóla (óutgefin doktorsritgerð). Háskóli Íslands, Reykjavík.

Svanhildur Kr. Sverrisdóttir, Ragnheiður Margrét Guðmundsdóttir og Sigurlína Davíðsdóttir. (2011). Úttekt á islenskukennslu i framhaldsskólum. Reykjavík: Mennta- og menningarmálaráðuneytið.

Trigwell, K. og Prosser, M. (2004). Development and use of the approaches to teaching inventory. Educational Psychology Review, 16(4), 409-424. doi:10.1007/s10648-004-0007-9

Waughan, W. (2002). Effects of cooperative learning on achievement and attitude among students of color. The Journal of Educational Research, 95(6), 359-364. doi:10.1080/00220670209596610

Öztürk, I. H. (2011). Curriculum reform and teacher autonomy in Turkey:The case of the history teaching. International Journal of Instruction, 4(2), 1308-1470. Sótt af https://files.eric.ed.gov/fulltext/ED522675.pdf

Ingvar Sigurgeirsson, Elsa Eiríksdóttir og Ingólfur Ásgeir Jóhannesson. (2018).

Kennsluaðferðir í 130 kennslustundum í framhaldsskólum.

Netla - veftímarit um uppeldi og menntun. Sérrit 2018 - Framhaldsskólinn í brennidepli. Menntavísindasvið Háskóla Íslands.

Sótt af http://netla.hi.is/serrit/2018/framhaldskolinn_brennidepli/09.pdf

DOI: https://doi.org/10.24270/serritnetla.2019.9 